\title{
Natural Zeolites in Water Treatment \\ - How Effective is Their Use
}

Karmen Margeta, Nataša Zabukovec Logar, Mario Šiljeg and Anamarija Farkaš

Additional information is available at the end of the chapter

http://dx.doi.org/10.5772/50738

\section{Introduction}

Natural zeolites are environmentally and economically acceptable hydrated aluminosilicate materials with exceptional ion-exchange and sorption properties. Their effectiveness in different technological processes depends on their physical-chemical properties that are tightly connected to their geological deposits. The unique treedimensional porous structure gives natural zeolites various application possibilities. Because of the excess of the negative charge on the surface of zeolite, which results from isomorphic replacement of silicon by aluminum in the primary structural units, natural zeolites belong to the group of cationic exchangers. Numerous studies so far have confirmed their excellent performance on the removal of metal cations from wastewaters. However, zeolites can be chemically modified by inorganic salts or organic surfactants, which are adsorbed on the surface and lead to the generation of positively charged oxihydroxides or surfactant micelles, and which enables the zeolite to bind also anions, like arsenates or chromates, in stable or less stable complexes. Natural zeolites have advantages over other cation exchange materials such as commonly used organic resins, because they are cheap, they exhibit excellent selectivity for different cations at low temperatures, which is accompanied with a release of non-toxic exchangeable cations $\left(\mathrm{K}^{+}\right.$, $\mathrm{Na}^{+}, \mathrm{Ca}^{2+}$ and $\mathrm{Mg}^{2+}$ ) to the environment, they are compact in size and they allow simple and cheap maintenance in the full-scale applications. The efficiency of water treatment by using natural and modified zeolites depends on the type and quantity of the used zeolite, the size distribution of zeolite particles, the initial concentration of contaminants (cation/anion), $\mathrm{pH}$ value of solution, ionic strength of solution, temperature, pressure, contact time of system zeolite/solution and the presence of other organic compounds and anions. For water treatment with natural zeolites, standard procedures are used, usually a procedure in column or batch process. Ion exchange and adsorption properties of natural zeolites in comparison with other chemical and biological processes have the advantage of 
removing impurities also at relatively low concentrations and allows conservation of water chemistry, if the treatment is carried out in the column process [1]. Subject of further academic and industrial research should be to improve the chemical and physical stability of modified zeolites and to explore their catalytic properties, which would allow their use in catalytic degradation of organic pollutants. More careful consideration of their superb metal removal properties and awareness of possible regeneration or further use of contaminant/metal-loaded forms can considerably increase their environmental application possibilities, with a focus the reduction of high concentrations of cations and anions in drinking water and wastewater, for surface, underground and public municipal water treatment independently or in combination with others physical chemical methods [2].

\subsection{Water treatment using natural zeolites}

\subsubsection{Wastewater treatment}

The use of natural zeolites in wastewater treatment is one of the oldest and the most perspective areas of their application. The presence of heavy metals $(\mathrm{Zn}, \mathrm{Cr}, \mathrm{Pb}, \mathrm{Cd}, \mathrm{Cu}, \mathrm{Mn}$, $\mathrm{Fe}$, etc.) in wastewater is a serious environmental problem and their removal by natural zeolites have been extensively studied along with other technologies, including chemical precipitation, ion exchange, adsorption, membrane filtration, coagulation flocculation, flotation and electrochemical methods [3]. Recent investigations of natural zeolites as adsorbents in water and wastewater treatment, their properties and possible modification of natural zeolites have been a subject of many studies. Various natural zeolites around the world have shown good ion-exchange capacities for cations, such as ammonium and heavy metal ions. Modification of natural zeolites can be performed by several methods, such as acid treatment, ion exchange, and surfactant functionalization. The modified zeolites can show high adsorption capacity also for organic matter and anions [4].

\subsubsection{Surface waters, ground and underground water treatment}

The applicability of natural zeolites for the simultaneous removal of ammonia and humic acid, two of the most encountered current contaminants, from the surface waters was also investigated. Their removal depends on $\mathrm{pH}$ value, initial concentrations of humic acid and ammonia, temperature and contact time. The obtained results indicated that zeolite showed best performance for simultaneous removal of ammonia and humic acid at the $\mathrm{pH}$ close to that of natural waters [5]. The use of natural and modified zeolites has been further investigated for the simultaneous removal of $\mathrm{Fe}$ and $\mathrm{Mn}$ ions from underground water samples. In particular, Fe and Mn removal levels are between $22-90 \%$ and $61-100 \%$ for natural zeolite - clinoptilolite [6]. The development of new and cost effective methods to remove As from ground water and drinking water also becomes one of the research priorities. The occurrence of arsenic in natural ground waters is due to geological composition of soil. 


\subsubsection{Drinking and grey water treatment}

Several conventional methods are used for the removal of pollutants from drinking water, such as coagulation followed by filtration, membrane processes and ion exchange. Adsorption methods proved to be effective, economically efficient, easy to perform and construct. Some experiments were conducted to study the efficiency of natural zeolite clinoptilolite and of the clinoptilolite-Fe system in removal of $\mathrm{Cu}, \mathrm{Mn}, \mathrm{Zn}$, which are simultaneously found in water samples. A very unique property of natural zeolites is their selectivity towards cationic. The excellent results of adsorption experiments, especially for the modified forms along with the fact that the clinoptilolite-Fe system is inexpensive, easily synthesized and regenerated, harmless for human beings, as well as for the environment, we can consider it as a very promising selective metal adsorbent [7]. Using iron/aluminum hydroxide to remove arsenic from water is a proven technology. An alternative method to enhance the performance is to use coarse-grained sorbents to increase the flow rate and throughput of the process. The removal of arsenic from drinking water was studied by using modified adsorbents (natural zeolite) prepared by the use of different iron solutions. The arsenic sorption on the Fe-exchanged zeolite could reach up to $100 \mathrm{mg} / \mathrm{kg}[8,9]$. The high surface area of modified natural zeolite (clinoptilolite)-iron oxide system in strongly basic conditions, can also enhance the removal of cations, like $\mathrm{Cu}$ from drinking water. The specific surface area of modified clinoptilolite increased up to 5-times (from 30 to $151 \mathrm{~m}^{2} / \mathrm{g}$ ) and the maximum amount of adsorbed $\mathrm{Cu}$ ions was $13.6 \mathrm{mg} / \mathrm{g}$ zeolite for natural clinoptilolite and $37.5 \mathrm{mg} / \mathrm{g}$ for modified clinoptilolite [10]. In spite of many scientific evidences of the effectiveness of zeolites in anion removal, not many of them are used on larger scales up to date. High concentrations of fluoride ions in groundwater up to more than $30 \mathrm{mg} / \mathrm{L}$, occur widely, notably in the United States of America, Africa and Asia. More than 260 million people worldwide consume drinking water with a fluoride content of $>1.0$ $\mathrm{mg} / \mathrm{L}$. The available techniques for the removal of $\mathrm{F}^{-}$-anions from drinking water are membrane techniques, dialysis, electro-dialysis and finally adsorption techniques. Clinoptilolite-type natural zeolite was pre-conditioned with nitric acid solution before loading with $\mathrm{Al}^{3+}$, $\mathrm{La}^{3+}$ or $\mathrm{ZrO}^{2+}$. Aluminium-loaded low-silica zeolites as adsorbents for fluorides showed that modified zeolites were able to defluoridate water to below WHO's maximum allowable concentration (MAC) of $1.5 \mathrm{mg} / \mathrm{L}$. The maximum fluoride adsorption was in the $\mathrm{pH}$ range of 4-8 [11]. High nitrate concentrations in drinking water sources can lead to a potential risk to environment and public health. Removal efficiency of $\mathrm{NO}_{3}$ - ions can be increased by treatment of the clinoptilolite samples with HDTM $^{+}$ (hexadecyltrimethylammonium cation) or cetylpyridinium bromide (CPB) [12]. Grey water is wastewater originated from bathroom and laundry in households. Ammonium is one of the most significant grey water contaminants. Natural and modified zeolites are used for their purification and they shows good performance with up to $97 \%$ of ammonium removal depending on contact time, zeolite loading, initial ammonium concentration and $\mathrm{pH}$ value. The desorption-regeneration studies demonstrated that the desorption of ammonium on the zeolite is sufficiently high $[13,14]$. 


\subsubsection{The technological application of natural zeolites in water treatment}

Numerous and excellent research results in the last 10 years have shown that natural zeolites have practical use, which is confirmed by a large number of patents, especially for the two naturally occurring zeolite minerals: clinoptilolite and modernite shown in Figure 1. The number of patents is substantial for both zeolite types, which gives a clear notice that the interest of researcher in natural zeolites is strongly encouraged by the commercial sector covering the use in households or in industrial/large-scale processes and treatments.

\begin{tabular}{l} 
Number of scientific research \\
Number of patents \\
\cline { 2 - 5 }
\end{tabular}

Figure 1. Number of patents for clinoptilolite (CLI) and mordenite (MOR), (The last ten years) [15].

\section{Properties of natural zeolites}

The structure of natural zeolite is very interesting and complex. The primary building units (PBU) of zeolites are the $\mathrm{SiO}_{4}$ and $\mathrm{AlO}_{4}$ tetrahedra. They connect via oxygen ions into secondary building units (SBU), which are then linked into a three-dimensional crystalline structure of zeolite. Substitution of $\mathrm{Si}$ by $\mathrm{Al}$ defines the negative charge of the zeolite framework, which is compensated by alkaline and earth alkaline metal cations. Therefore natural zeolites appear as cation exchangers because they have negative charge on the surface. In the zeolite lattice, substitution is not limited to Si-Al substitution. Atoms of iron, boron, chromium, germanium, and titanium may also substitute silicon. Water molecules can be present in voids of large cavities and bonded to framework ions and exchangeable ions via aqueous bridges. One of the most investigated zeolite in basic and applied research is clinoptilolite. The characteristic way of linking of PBUs and the formation of unique structural units ultimately results in the fact that these materials are highly porous with channels and cavities in the structure that have characteristic pore sizes and shapes. In the structure of clinoptilolite, there are three types of channels, of which two are parallel, and made of ten and eight-membered rings of $\mathrm{Si} / \mathrm{AlO}_{4}$, while one, defined by eight-membered rings, is vertical. In these channels the hydrated cations can occupy the following places: I cation (Na- and Ca-ions) is located in the 10-member ring channels (free diameters $0.44 \mathrm{x}$ $0.72 \mathrm{~nm}$ ); II - cation (Na- and Ca-ions) is located in the 8-member ring channels (free diameters $0.41 \times 0.47 \mathrm{~nm}$ ); III - cation (K-ion) is located in the 8-member ring vertical channels (free diameters $0.40 \times 0.55 \mathrm{~nm}$ ); IV - cation (Mg-ion) is located in the channel of 10member rings and it is located in the center of the channel (Figure 2). 


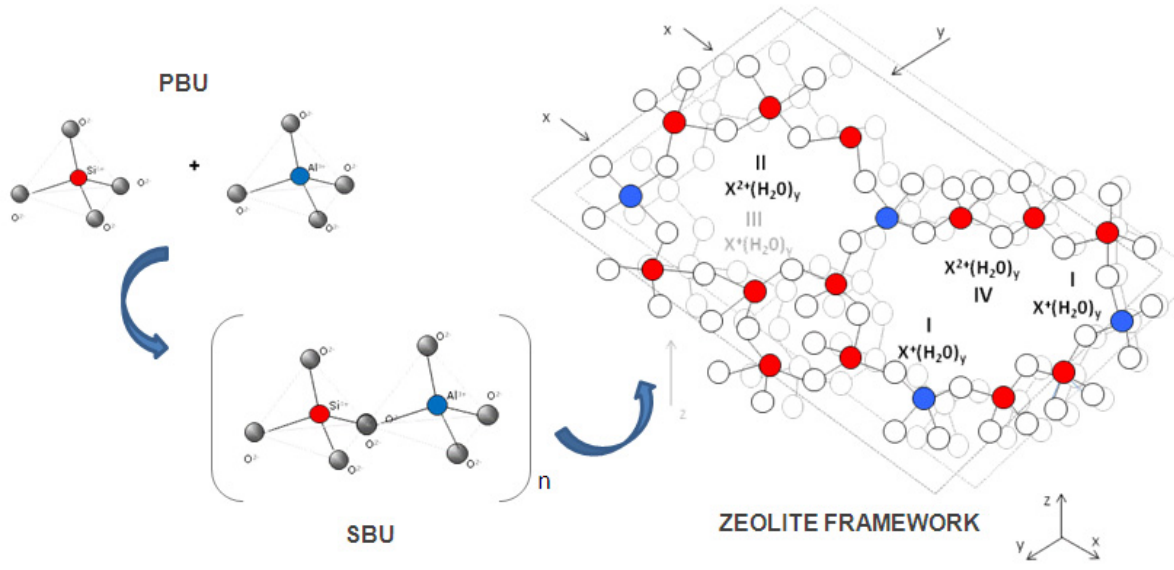

Figure 2. Binding of building units (PBU and SBU) in three-dimensional zeolite- clinoptilolite structure.

Usually the number of water molecules in the zeolite structure does not exceed the number of oxygen atoms. Ratio $(\mathrm{Si}+\mathrm{Al})$ : $\mathrm{O}$ is $1: 2$, and the number of aluminum atoms in the tetrahedrons is equal to the sum of the positive charges $(x+2 y)$ of exchangeable cations. Replacement of silicon and aluminum atoms in zeolites ranges from a minimum ratio of 1:5 (mordenit), up to a maximum 1:1 (erionit) [16].

\subsection{Categorization and characterization of natural zeolites}

Natural zeolites are divided into seven main groups (Table 1) according to their crystal structure, based on morphology, their physically properties, different ways of binding secondary units in the three-dimensional framework, the free pore volume and types of exchangeable cations in zeolite structure. These diverse types of zeolite are a reflection of the fascinating structures of these microporous materials. Each time a new zeolite framework structure is reported, it is examined by the Structure Commission of the International Zeolite Association (IZA-SC), and if it is found to be unique, it is assigned a 3-letter framework type code, like CLI, MOR, ANA etc. This code is part of the official IUPAC nomenclature for microporous materials [17]. Characterizations of natural zeolites include chemical and instrumental analyses of the samples and are crucial for their further application in water treatment. The chemical composition, usually determined by several different methods: classical chemical analysis - gravimetric method, Atomic Absorption Spectrometry or X-ray Fluorescence Spectrometry, is very important for the efficiency of the water treatment processes and provides insight into the main amount of basic oxide components $\left(\mathrm{SiO}_{2}\right.$ and $\left.\mathrm{Al}_{2} \mathrm{O}_{3}\right)$, exchangeable cations $\left(\mathrm{Na}^{+}, \mathrm{K}^{+}, \mathrm{Ca}^{2+}, \mathrm{Mg}^{2+}, \mathrm{Ba}^{2+}, \mathrm{Sr}^{2+}\right)$ and other elements present in smaller concentrations (like Ti atoms). According to the proportion of exchangeable cations, we can sometimes already determine the type of zeolite. The proportion of the oxide components in natural zeolite materials depends on the geological deposits. Table 2 gives the basic information of the chemical composition of natural zeolites, from different countries expressed as mass fraction of oxide components. 


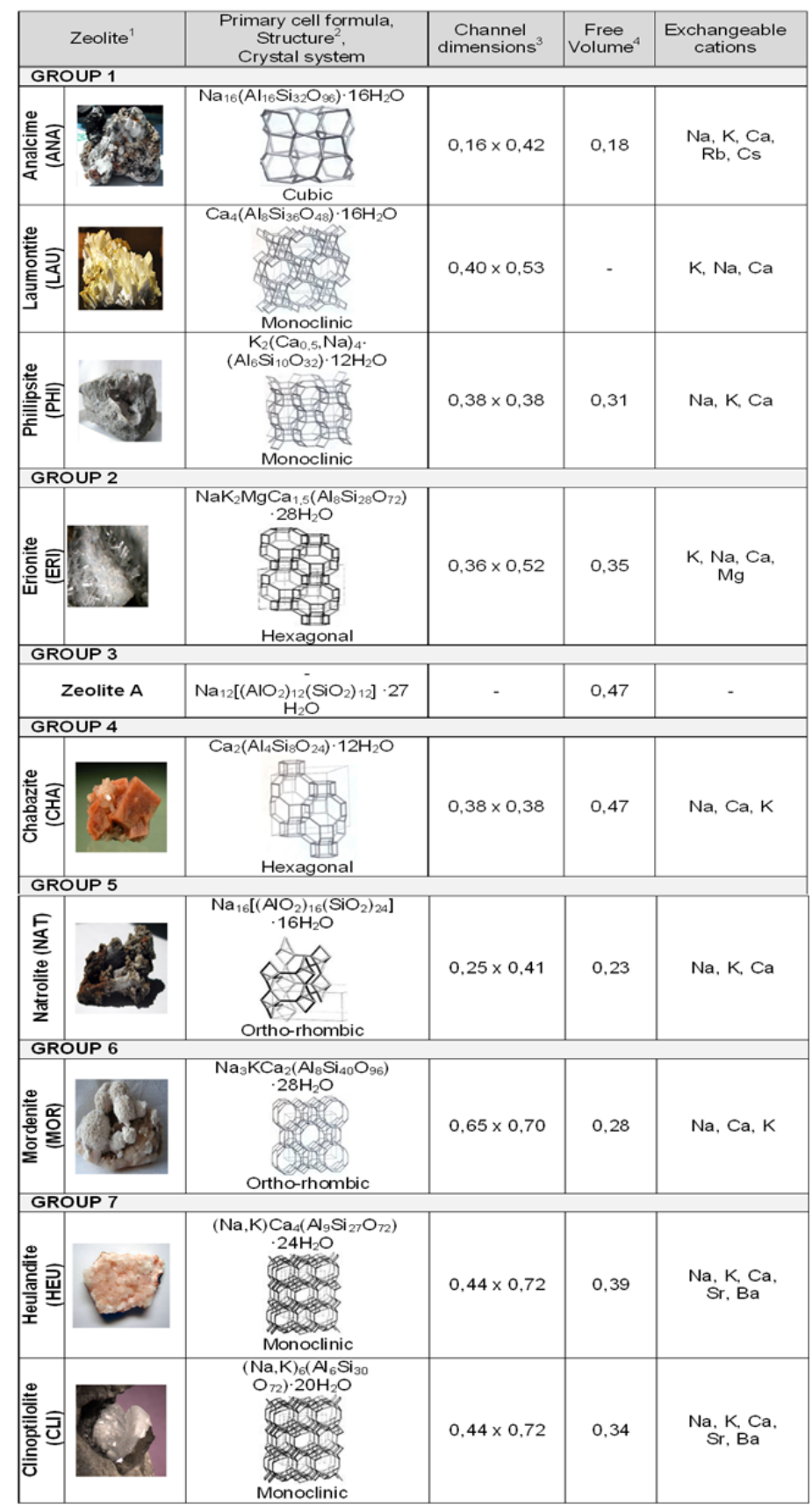

${ }^{1}$ Web pictures (http://www.galleries.com/Zeolite_Group), ${ }^{2}$ Atlas of Zeolite Framwork [16]., ${ }^{3}$ Dimension (nm) is the dimension of the largest channel, ${ }^{4} \mathrm{~mL} \mathrm{H}_{2} \mathrm{O} / \mathrm{mL}$ zeolite

Table 1. Categorization and structural properties of seven main groups of natural zeolites. 


\begin{tabular}{|l|c|c|c|c|c|c|c|c|c|}
\hline \multirow{2}{*}{ Zeolite } & \multicolumn{7}{|c|}{ Components, wt (\%) } & & \\
\cline { 2 - 10 } & $\mathrm{SiO}_{2}$ & $\mathrm{Al}_{2} \mathrm{O}_{3}$ & $\mathrm{Fe}_{2} \mathrm{O}_{3}$ & $\mathrm{Na} 2 \mathrm{O}$ & $\mathrm{K} 2 \mathrm{O}$ & $\mathrm{CaO}$ & $\mathrm{MgO}$ & LOI$^{*}$ & Ref. \\
\hline \hline Croatia (CLI) & 64,93 & 13,39 & 2,07 & 2,40 & 1,30 & 2,00 & 1,08 & 9,63 & {$[18]$} \\
\hline Serbia (CLI) & 65,63 & 12,97 & 1,48 & 1,20 & 1,33 & 3,21 & 1,41 & 12,96 & {$[19]$} \\
\hline Australia (CLI) & 68,26 & 12,99 & 1,37 & 0,64 & 4,11 & 2,09 & 0,83 & 8,87 & {$[20]$} \\
\hline Mexican (CLI) & 70,17 & 11,07 & 1,12 & 0,83 & 4,90 & 1,73 & 0,35 & - & {$[21]$} \\
\hline China (CLI) & 65,72 & 13,50 & 1,30 & 1,16 & 3,14 & 3,10 & 0,63 & 11,12 & {$[22]$} \\
\hline Turkey (CLI) & 64,28 & 12,07 & 0,84 & 5,62 & 0,83 & 2,47 & 2,07 & - & {$[23]$} \\
\hline Cuba (CLI) & 64,30 & 11,00 & 1,4 & 1,40 & 1,20 & 3,70 & 0,50 & - & {$[24]$} \\
\hline Bulgaria (CLI) & 64,20 & 11,67 & 1,03 & 2,36 & 3,84 & 7,42 & 0,35 & 8,66 & {$[25]$} \\
\hline Greece (HEU) & 68,62 & 11,80 & 0,07 & 1,13 & 2,92 & 2,14 & 0,75 & 12,34 & {$[26]$} \\
\hline Ukraine (CLI) & 68,64 & 11,50 & 1,57 & 0,29 & 3,12 & 2,38 & 0,89 & - & {$[27]$} \\
\hline Equador (CLI) & 65,80 & 11,32 & 3,42 & 4,10 & 0,45 & 1,23 & 0,96 & 12,29 & {$[28]$} \\
\hline Brazil (STI) & 68,79 & 11,71 & 5,25 & 2,75 & 0,62 & 3,34 & 1,31 & 5,84 & {$[28]$} \\
\hline Italia (PHI) & 52,47 & 17,57 & 3,70 & 0,92 & 7,47 & 4,99 & 1,50 & 9,48 & {$[29]$} \\
\hline Argentina (CLI) & 64,51 & 11,25 & 0,97 & 3,60 & 1,21 & 4,38 & 0,60 & 13.14 & {$[29]$} \\
\hline USA (CLI) & 66.61 & 12,91 & 1,7 & 0,39 & 2,44 & 3,18 & 1,54 & 10,72 & {$[30]$} \\
\hline
\end{tabular}

CLI - clinoptilolite; STI - stilbite; PHI - philipsite; HEU - heulandite

*LOI - Loss of ignition

Table 2. Chemical composition of natural zeolites from different deposits.

Because of the complex mineralogical composition of natural zeolites and consequently uneven distribution of different phases and elements in the zeolite tuff, a combination of microscopic, spectroscopic, and other instrumental techniques must be used to fully characterize the material. The basic information about the accessibility of the pores for different ions and molecules can be obtained from BET Analysis based on nitrogen physisorption, which gives information about the BET surface and accessibility of the pores for different ions and molecules. The BET values usually range from 15 to $40 \mathrm{~m}^{2} / \mathrm{g}$ [19]. X-ray powder diffraction analysis allows quantitative determination of mineralogical composition of zeolitic tuffs, including the type of zeolite, and is crucial for any further application of natural zeolites. A typical X-ray powder diffractogram is shown on Figure 3. Detailed studies of some zeolite tuffs from Croatia and Serbia by powder X-ray diffraction and subsequent quantitative Rietveld refinement phase analyses are shown in Figure 4. 


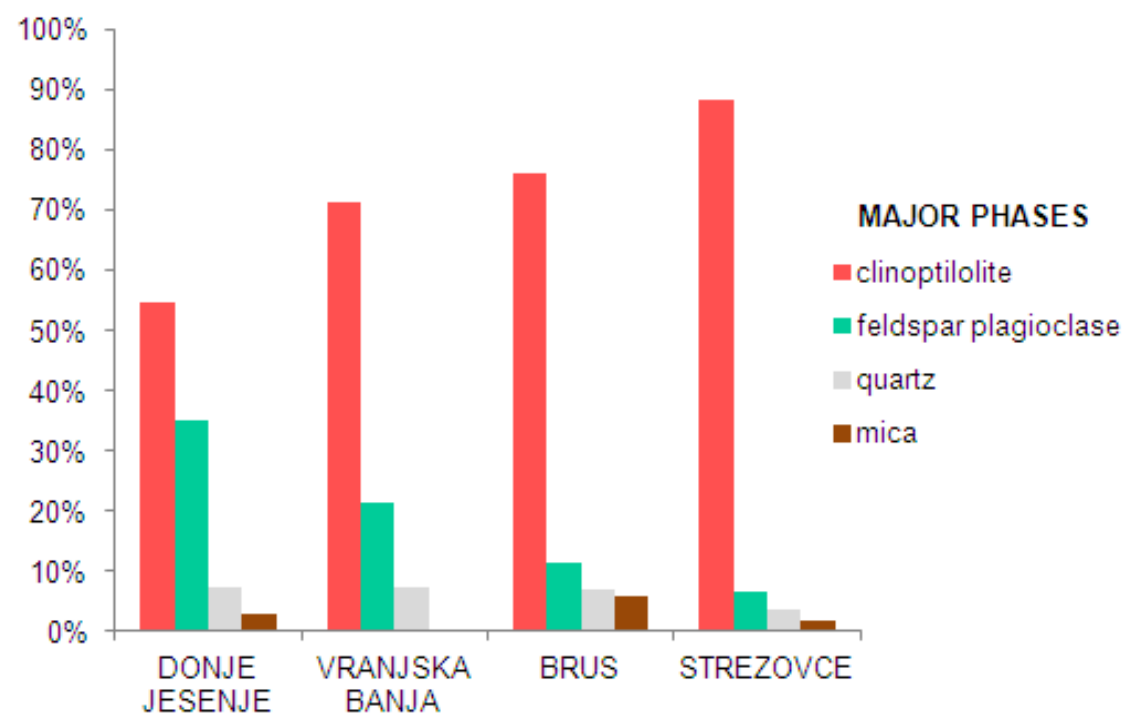

Figure 3. The phase composition of zeolite tuffs from different deposits

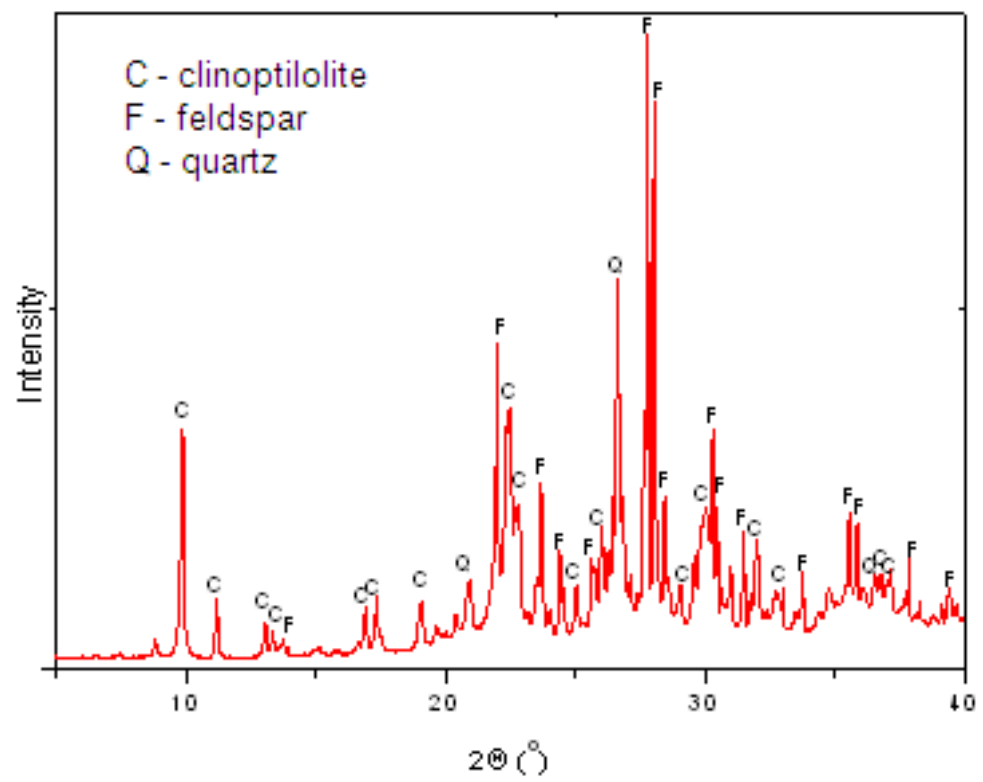

Figure 4. XRPD of natural zeolite [18].

The size and the morphology of the crystals in the zeolite samples is usually studied by scanning electron microscopy and accompanied Energy Dispersive X-ray Spectroscopy 
(EDXS) analysis system, that is attached to the scanning electron microscope. The obvious advantage of EDXS elemental analysis over conventional chemical analysis is that we can obtain elemental composition of selected phase in the tuff, not only in the bulk sample. An average elemental composition of the sample using EDXS is usually obtained by a data collection at three or more different $\mathrm{mm}^{2}$ - sized windows on the sample surface. Typical SEM photographs of zeolite tuffs are shown in the figure below (Figure 5).

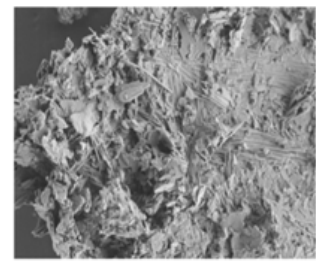

(a)

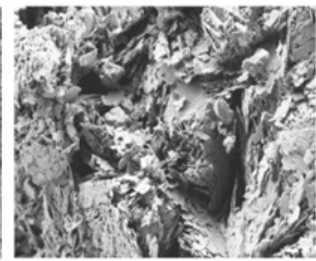

(b)

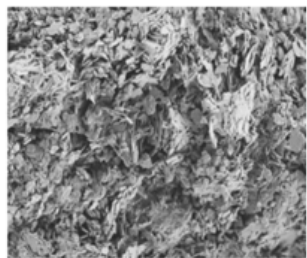

(c)

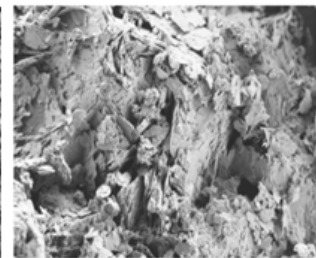

(d)

Figure 5. SEM of zeolite tuffs from Donje Jesenje (a), Vranjska Banja (b), Brus (c) and Strezovce (d). Magnification of app. 20.000x was used in the measurements. Beside the typical plate-like morphology of clinoptilolite crystals, some fiber-like particles of mordenite could be also observed in all four samples.

The X-ray Photoelectron Spectroscopy (XPS or ESCA) analysis is used to determine the type and oxidation state of elements on the surface of natural zeolite by $\mathrm{X}$-ray radiation from anode, e.g. Al anode, mostly by putting the sample in the form of $1 \mathrm{~mm}$ thick pressed pallet. XPS depth profiling can be performed by alternating cycles of ion sputtering to remove surface layers of zeolite and acquisition of photoelectron spectra (ion sputtering can be performed with $1 \mathrm{keV} \mathrm{Ar}^{+}$beam rastering over $3 \times 3 \mathrm{~mm}^{2}$ area). In this way a depth distribution of elements can be obtained. The relative error for calculated concentrations of metals is estimated to be about $20 \%$.

The X-ray absorption spectroscopy (XAS) is a particularly useful method for the characterization of metal-loaded zeolite samples. Information on the oxidation state of metals, like copper, zinc, chromium, arsenic and many others, in natural zeolites can be obtained by XANES (X-ray Absorption Near Edge Structure). The energy position of the metal absorption edge is shifted to higher energies with increasing oxidation state. The relation can be calibrated with XANES spectra of reference compounds with the same type of metal ligands as in the investigated sample. More information on the local environment of metal atoms in the zeolite samples can be obtained by EXAFS (Extended X-ray Absorption Fine Structure) analysis. The EXAFS spectra can be quantitatively analyzed for the coordination number, distance, and Debye- Waller factor of the nearest coordination shells of the metal.

\section{Modifications of natural zeolite}

Natural zeolite can be modified by single or combined treatment such as heating and chemical modification (acids, bases and inorganic salts). Chemical and thermal treatment of 
zeolite may result in cation migration and thus affect the cation location and pore opening. "Pore engineering" is a popular term for methods used in zeolite modification in which some of its sorbent properties are manipulated. The processes of ion exchange and adsorption in zeolite/solution contact occur concurrently.

\subsection{Modification with solution of inorganic salts}

Chemical modification with inorganic salts $\left(\mathrm{NaCl}, \mathrm{CaCl}_{2}, \mathrm{BaCl}_{2}, \mathrm{NH}_{4} \mathrm{Cl}, \mathrm{FeCl}_{3}\right)$ or a cationic surfactant (hexsadecyltri-methylammonium (HDTMA) - bromide) give to improve zeolite properties and increase its efficiency in water treatment [19, 31-38]. For successful modification high-concentration solutions of inorganic salts on the surface of zeolite is significant as shown in Figure 6. Under normal conditions, large cavities and entries to the channels inside the zeolite framework are filled with water molecules forming hydration spheres around exchangeable cationic (Figure 6-A). After the contact of zeolite with an inorganic salt solution such as $\mathrm{NaCl}$, exchange of cations $\left(\mathrm{H}^{+}\right.$or $\left.\mathrm{Na}^{+}\right)$from solution with exchangeable cations $\left(\mathrm{Na}^{+}, \mathrm{K}^{+}, \mathrm{Ca}^{2+}, \mathrm{Mg}^{2+}\right)$ from the zeolite framework occurs (Figure 6-B). To remove anions from the water, zeolite surface has to be modified with a solution of inorganic salts (for example $\mathrm{FeCl}_{3}$ ) whose adsorption on the zeolite surface leads to the formation of oxi-hydroxides, which then form stable complexes with anions in solution. This modification can result in - to a smaller or greater extent - the creation of an adsorption layer on zeolite surface and modification of surface charge on zeolite surface (from negative to positive) (Figure 6-C) [39,40]. Specific surface area (BET) of natural and modified zeolite (deposits from Croatia and Serbia) after pre-treatment with inorganic salts is shown in Table 3.
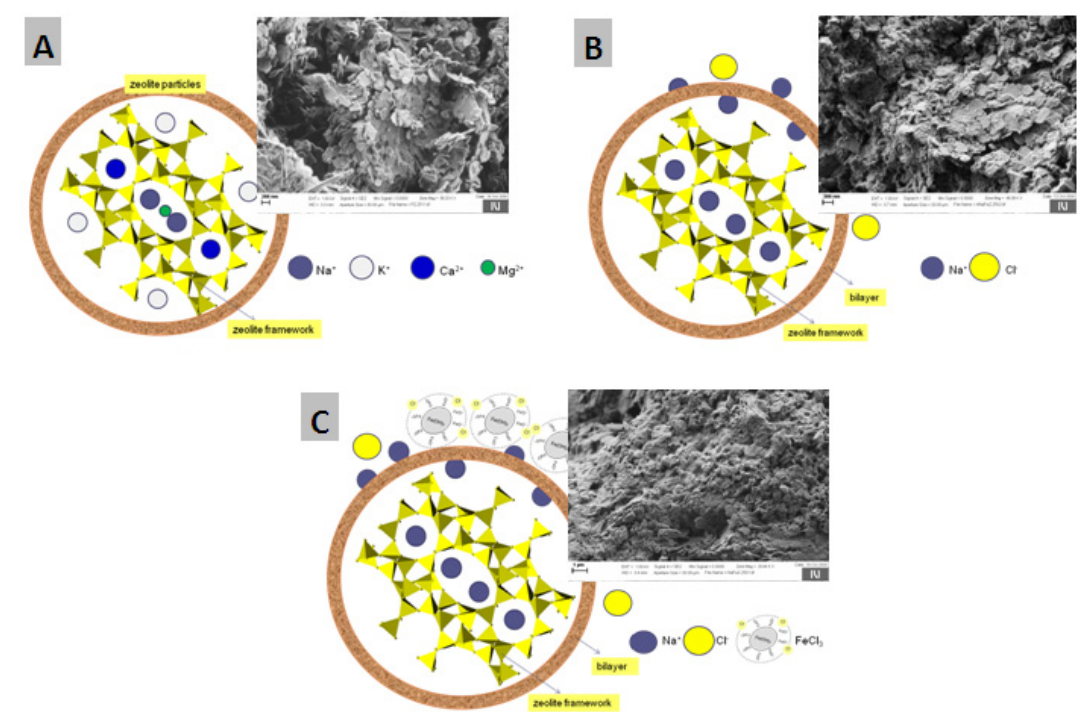

Figure 6. Zeolite particles in natural and modified zeolites (Na and Fe forms of clinoptilolite from the deposit V. Banja, Serbia) and SEM image of zeolite surface after the implementation of chemical modification. 


\begin{tabular}{|l|c|c|}
\hline \multirow{2}{*}{ Zeolite } & BET & Ref. \\
\hline \hline Natural CLI (VB) & Specific surface area, $\mathrm{m}^{2} / \mathrm{g}$ & {$[8]$} \\
\hline Natural CLI (DJ) & 24 & {$[8]$} \\
\hline Ca-CLI (VB) & 20 & {$[19]$} \\
\hline Na-CLI (VB) & 23 & {$[19]$} \\
\hline H-CLI $(0,5 \mathrm{M})(\mathrm{DJ})$ & 40 & {$[18]$} \\
\hline H-CLI $(1,0 \mathrm{M})(\mathrm{DJ})$ & 42 & {$[18]$} \\
\hline NaOH-CLI (DJ) & 19 & {$[18]$} \\
\hline NaFe-CLI (VB) & 91 & {$[8]$} \\
\hline NaFe-CLI (DJ) & 51 & {$[8]$} \\
\hline Natural MOR & 42 & {$[41]$} \\
\hline HDTMA (0,25 mmol/g)-MOR & 6 & {$[41]$} \\
\hline HDTMA (0,85 mmol/g)-MOR & 5 & {$[41]$} \\
\hline
\end{tabular}

Table 3. Specific surface area of natural and modified zeolites (clinoptilolite and mordenite) from Croatia (DJ) and Serbia (VB).

This confirms the theoretical study of the suitable position of $\mathrm{Na}^{+}$ions in zeolite structure and possibilities of zeolite exchange with metal ions from solutions. Na-modifications have shown the highest selectivity for zinc ions when $\mathrm{Zn}^{2+}$ ions are mixed together with $\mathrm{Fe}^{3+}$ ions, which is highly dependent on the acidity of the solution and cation hydratation enthalpy. Chemical modification of zeolite with $\mathrm{FeCl}_{3}$ solutions is defined by the parameter system: $\mathrm{pH}$ solution, ionic strength of the solution, oxidation-reduction conditions, iron concentration and the type of salts used (chlorides, sulphates, nitrates, perchlorates, etc.). $\mathrm{Fe}^{2+}$ and $\mathrm{Fe}^{3+}$ ratio results in sorption of iron ions and iron oxi-hydroxides on the surface and in the pores of clinoptilolite. However, regardless of the portion of different iron forms present in zeolite structure, the common property of all iron modified zeolites is a high increase in sorption capacity for arsenic oxi-anions present in water solutions. According to literature data, two mechanisms of arsenic binding on the surface of iron oxi- hydroxide are: the mechanism of surface precipitation and the mechanism of surface complexation. Surface complexation mechanism can be monodentate, dominant at a low surface coverage of modified zeolite, or bidendate at higher surface coverage when iron forms complexes with arsenic [42-44].

\subsection{Modification with $\mathrm{acid} / \mathrm{basic}$ treatment}

Zeolite structure and its chemical and physical properties can be modified with either inorganic basic $\left(\mathrm{NaOH}, \mathrm{Ca}(\mathrm{OH})_{2}\right)$ or acid solutions $\left(\mathrm{HCl}, \mathrm{HNO}_{3}\right)$. Acid treatment is among the most common and simple methods for zeolite modification. The effectiveness of acid treatment depends on the chemical composition, structure, mineral purity, and the working conditions. Dissolution of some amorphous materials that block the pores of natural zeolites is another consequence of acid modification. According to the Brønsted and Lewis theory, 
dissolution of natural zeolites in acid solution occurs as a result of the acidic/basic behaviour of the aluminosilicate structure in the presence of $\mathrm{H}^{+}$or $\mathrm{OH}^{-}$ions in the solution. Brønsted and Lewis acidic/basic sites present in the zeolite framework are also responsible for their chemical behaviour in aqueous solutions. Interactions of natural high-silica zeolites (e.g. clinoptilolite, heulandite, mordenite, erionite and ferrierite) with acidic and basic aqueous media generally occurring at low dissolution rates and are adequately acid-resistant [26]. By the dealumination process, $\mathrm{Al}^{3+}$-ions can be progressively removed from the aluminosilicate structure. The reactions favour lower $\mathrm{pH}$ values and the $\mathrm{AlOH}_{2}{ }^{+}$species formed are detached because of their high degree of surface protonation. Decationization (exchange of zeolite cations with $\mathrm{H}+$ ions) is minimal in solutions with high cation concentrations but is also significantly dependent on the solution acidity and cation hydratation enthalpy [45]. Hydrochloric acid solution treatment leads to decationization (obtaining the so-called "hydrogen form" zeolites), dealuminization and sometimes destruction of the crystal lattice. The effect of hydrochloric acid on various zeolites varies. As an example, the $\mathrm{HCl}$ acid modification of the natural materials mordenite and erionite conducted under similar conditions led to weak decationization and almost no dealuminization of mordenite, while the extent of alkaline and alkaline earth metals uptake, as well as of aluminium uptake from erionite was more than 90 $\%$ [25]. Changes in the chemical composition and structure of zeolites as a result of the decationization and dealumination steps lead to changes of minerals properties. The nature of the mineral and the exchangeable cation content, as well as impurities, have a significant influence on acid modification of structurally identical natural zeolites. Zeolite/solution contact time, heating before and after modification, pre-treatment with water or other solutions, such as $\mathrm{NH}_{4} \mathrm{Cl}$, influence the efficiency of modification as well. Low siliceous zeolites are unstable in the acid and their decationization is conducted by other methods. Ion exchange with more soluble ammonium salts (usually $\mathrm{NH}_{4} \mathrm{Cl}$ ) is the initial stage, followed by heating of the samples rich in ammonium ions to eliminate ammonia and hydrogen. This method of decationization is also applied to highly siliceous zeolites. Influence of the concentration of modification solution and the reaction time are also taken into consideration.

\section{Hydrothermal treatment of natural zeolite}

Thermal treatment at high temperature, depending on the solid sample and temperature used can enhance pore volume by removing water molecules and organics from pore channels. Water present in cages and channels of the zeolite framework contributes $10-25$ $\%$ to the total mass of zeolites. To enable efficient use of zeolites in water treatment, it is important to know the properties of dehydration and structural stability of particular zeolitic materials. Stability in the structure of some natural zeolites is given in Table 4 .

To acquire information about the mass loss change and adsorption or crystallization, thermal analysis methods are used: thermogravimetric/differential thermogravimetric analysis (TG/DTG) and differential thermal analysis (DTA). A stable zeolite structure, such as clinoptilolite, results in continuing, but reversible loss of water. The dehydration process of natural and modified zeolites and zeolite mass loss rate by increasing temperature are shown in Figure 7. 


\begin{tabular}{|c|c|}
\hline Natural zeolite & Structural stability \\
\hline \hline Analcime & up to $700^{\circ} \mathrm{C}$ \\
\hline Laumontite & up to $500^{\circ} \mathrm{C}$ \\
\hline Erionite & up to $750^{\circ} \mathrm{C}$ \\
\hline Mordenite & up to $800^{\circ} \mathrm{C}$ \\
\hline Heulandite & up to $300^{\circ} \mathrm{C}$ \\
\hline Clinoptilolite & up to $750^{\circ} \mathrm{C}$ \\
\hline
\end{tabular}

Table 4. Structural stability of some natural zeolites [16].

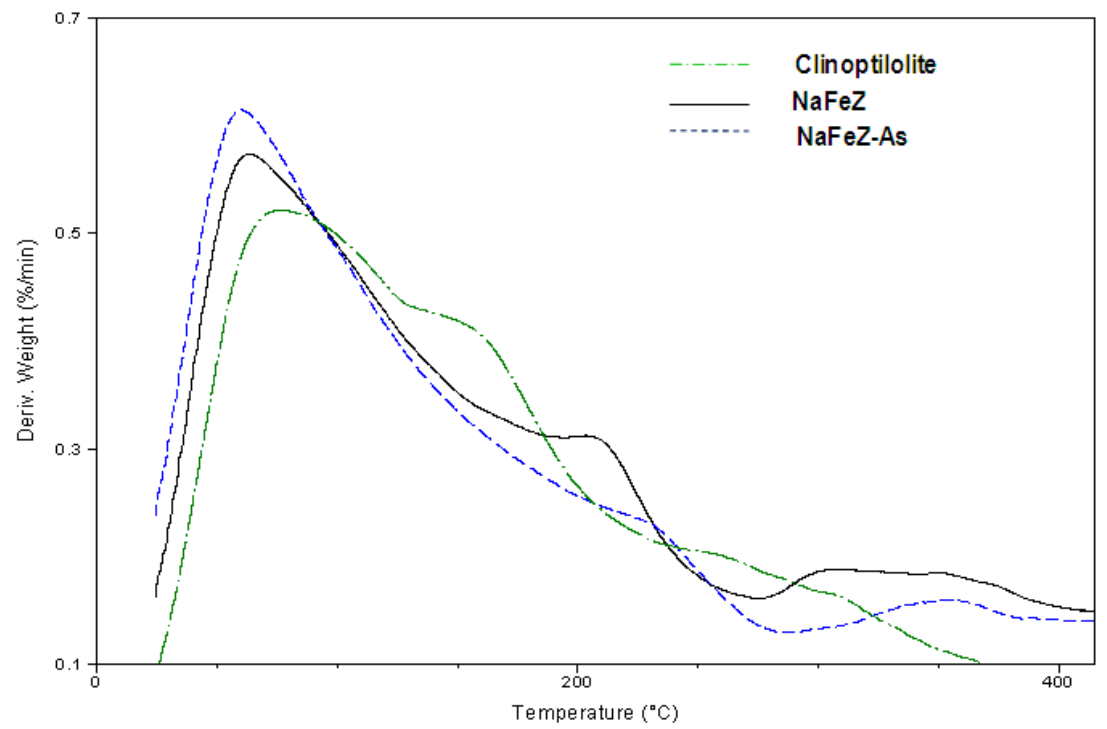

Figure 7. Loss of mass for natural and Fe-modified and Na-modified zeolite by the DTG method.

Zeolite water can be removed by heating to approximately $400{ }^{\circ} \mathrm{C}$. The hydration of iron modified zeolite was $17 \%$ higher than that of Na-modified zeolite and natural zeolite.

\section{Adsorption and ion exchange processes in water treatment}

A large number of parameters can influence the process of ion sorption/removal from water treatment. Conductivity, $\mathrm{pH}$, temperature of treated water, ionic strength, initial concentration of cations and anions in solution, zeolite mass, zeolite particle size are all important parameters.

\subsection{Processes of ion exchange, adsorption and hydrolysis}

Ion exchange process is characterized by the capacity, selectivity and kinetics of the exchange. Capacity is needed in several determinations, such as the normalization of 
equilibrium isotherms and the application of kinetic models in order to determine the ionexchange diffusion coefficients (Table 5). Differences in the exchange isotherms derived by different researchers for the same ion-exchange systems are mainly due to the assumption of different cation-exchange capacities of zeolitic materials.

IUPAC recommendations for ion-exchange nomenclature define the following capacity types: "Theoretical (specific) capacity, apparent capacity (effective capacity)", "Practical (specific) capacity", "Useful capacity" and "Breakthrough capacity" [46].

\begin{tabular}{|l|c|c|}
\hline Zeolite & Si/Al ratio & $\begin{array}{c}{ }^{*} \text { CEC, } \\
\text { meq/g zeolite }\end{array}$ \\
\hline \hline Analcime & $1,4-3,0$ & 4,5 \\
\hline Chabasite & $1,4-4,3$ & 3,7 \\
\hline Clinoptilolite & $2,7-5,7$ & 2,2 \\
\hline Erionite & $2,3-3,4$ & 3,1 \\
\hline Heulandite & $4,0-6,1$ & 3,2 \\
\hline Laumontite & $1,3-3,3$ & 4,3 \\
\hline Mordenite & $4,17-5,0$ & 2,3 \\
\hline Phillipsite & $1,7-3,3$ & 3,9 \\
\hline Natrolite & 1,5 & 5,2 \\
\hline
\end{tabular}

Table 5. Cation-exchange capacities of different zeolitic materials ( ${ }^{*} \mathrm{CEC}$ is operationally defined determine the amount of a cation that can be removed by a specific substance once the material and solution have come to equal) [16].

Zeolites selectivity related to cations and anions is an important property in water treatment procedure. Selectivity is a property of the exchanger to show different preferences for particular ions and it depends of field strength in zeolite pore. Zeolites with low field strength and with higher Si content, such as clinoptilolite, are more selective for cations with lower charge density $\left(\mathrm{K}^{+}, \mathrm{NH}_{4}{ }^{+}, \mathrm{Ag}^{+}, \mathrm{Cs}^{+}\right)$. Zeolites with high field strength, i.e. higher $\mathrm{Al}$ content, are more selective toward the high charge density cations $\left(\mathrm{Na}^{+}, \mathrm{Li}^{+}\right)$. At room temperature and low concentration of the solution ions are exchanged, the advantages of the amendment have ions with higher charge. Increasing the concentration of the solution, the difference in ion exchange affinities of different charges is reduced. If the solution contains different ions of the same charge, the selectivity increases with increasing atomic number $\left(\mathrm{Li}^{+}, \mathrm{Na}^{+}, \mathrm{NH}_{4}{ }^{+}, \mathrm{K}^{+}\right)$. The selectivity of clinoptilolite towards alkali metals exist in the sequence: $\mathrm{Cs}^{+}>\mathrm{K}^{+}>\mathrm{Rb}^{+}>\mathrm{Na}^{+}>\mathrm{Li}^{+}$, and the alkaline earth metals: $\mathrm{Ba}^{2+}>\mathrm{Sr}^{2+}>\mathrm{Ca}^{2+}>\mathrm{Mg}^{2+}$. The selectivity of clinoptilolite towards heavy metal ions (cations) exist in the series: $\mathrm{Pb}^{2+}>\mathrm{Cd}^{2+}>$ $\mathrm{Cu}^{2+}>\mathrm{Co}^{2+}>\mathrm{Cr}^{2+}>\mathrm{Zn}^{2+}>\mathrm{Mn}^{2+}>\mathrm{Hg}^{2+}$ and selectivity by anions exists in the series: $\mathrm{SO}_{4}{ }^{2->} \mathrm{I}>$ $\mathrm{NO}_{3}^{-}>\mathrm{HCrO}_{4}^{-}>\mathrm{Br}^{-}>\mathrm{Cl}^{-}>\mathrm{OH}^{-}[47,48]$

The processes of ion exchange and adsorption on natural zeolite occur concurrently with the process of hydrolysis in aqueous solutions. Determination of hydrolytic activity and stability of zeolites according to previous studies showed a very important aspect of technological applications, and hydrolytic activity indicates the chemical stability. 
The hydrolysis process (1) is a reaction following the process of ion exchange. Understanding and studying zeolite hydrolysis is of great importance to understanding the properties of zeolite. The hydrolysis process of zeolite is usually observed by monitoring the $\mathrm{pH}$ levels and electric conductivity during which a sudden increase in the $\mathrm{pH}$ value can be seen at beginning of the hydrolysis process after which the zeolite-water system tends to stabilize the $\mathrm{pH}$ value.

$$
\mathrm{Me}-\mathrm{Z}(\mathrm{s})+\mathrm{H}_{2} \mathrm{O}(\mathrm{l}) \Leftrightarrow \mathrm{H}-\mathrm{Z}(\mathrm{s})+\mathrm{Me}^{\mathrm{n}+}(\mathrm{l})+\mathrm{n} \mathrm{OH}^{-}(\mathrm{l})
$$

$\mathrm{n}$ - cation charge, $\mathrm{Me}$ - exchangeable cations $\left(\mathrm{Na}^{+}, \mathrm{K}^{+}, \mathrm{Ca}^{2+}, \mathrm{Mg}^{2+}\right), \mathrm{Z}$ - zeolite

The created $\mathrm{OH}^{-}$ions cause an increase in the $\mathrm{pH}$ value of the system. A reaction of the metallic ions occurs at the same time (2).

$$
\mathrm{Me}^{\mathrm{n}+}(\mathrm{ls})+\mathrm{H}_{2} \mathrm{O}(\mathrm{l}) \Leftrightarrow[\mathrm{MeOH}]^{+}(\mathrm{l})+\mathrm{H}^{+}(\mathrm{l})
$$

Increase in the concentration of $\mathrm{OH}^{-}$ions at the beginning of hydrolysis causes thus created $\mathrm{OH}^{-}$ions to adsorb onto the surface of zeolitic particles, which in turn causes melting of the surface layer of zeolitic particles. Anions on the zeolite surface form with exchangeable cations more or less stable complexes, depending on the stability constant (3).

$$
\mathrm{Me}^{\mathrm{n}+}(\mathrm{l})+\mathrm{mA}^{\mathrm{y}-}(\mathrm{l}) \Leftrightarrow\left(\mathrm{MeAm}^{\mathrm{n}-\mathrm{my}}(\mathrm{l})\right.
$$

Hydrolysed cations in the channels have good mobility and ability to exchange with the cations from the solution because they are connected by weak electrostatic bonds to the basic aluminium-silicate structure. The rate of exchange and the quantity of exchangeable ions depend on the size of cations and their charge, cation concentration in the solution, ionic strength of the solution, anions present in the solution, temperature, $\mathrm{pH}$ value, physical and chemical properties of the solvent, structural characteristics of zeolite and exchange kinetics. Exchange of ions is preceded by the adsorption of ions from the solution to the surface of zeolite particles. Ion exchange (4) is a reversible process where a balance between the solid and fluid phases is achieved. During the process of achieving balance within the zeolite-solution system, a reversible process occurs.

$$
\operatorname{Me} 1 Z(s)+\operatorname{Me}_{2}{ }^{n+}(1) \Leftrightarrow M e 2 Z(s)+\operatorname{Me}^{n+}(1)
$$

$\mathrm{Me}_{1} \mathrm{Z}$ and $\mathrm{Me}_{2} \mathrm{Z}$ - concentrations of exchangeable cations $\mathrm{Me}_{1}$ and $\mathrm{Me}_{2}$ in zeolite $\mathrm{Z}$

$\mathrm{Me}_{2}{ }^{\mathrm{n}+}$ and $\mathrm{Me}_{1}{ }^{\mathrm{n}+}-$ concentrations of exchangeable cations in the solution

$\mathrm{n}$ - the charge number of exchangeable cations

The process of diffusion in the system of zeolite/ aqueous solution can be divided into several phases (Figure 8): (I) Diffusion in solution, (II) Diffusion through the film, (III) Diffusion in pores, (IV) Ion exchange.

It is known that the rate of a multistep chemical reaction is defined by the slowest stage. The rate of these processes can be changed by altering the physical characteristics of the heat exchanger or the solution containing the ions. Thus the rate of diffusion of ions in the film 


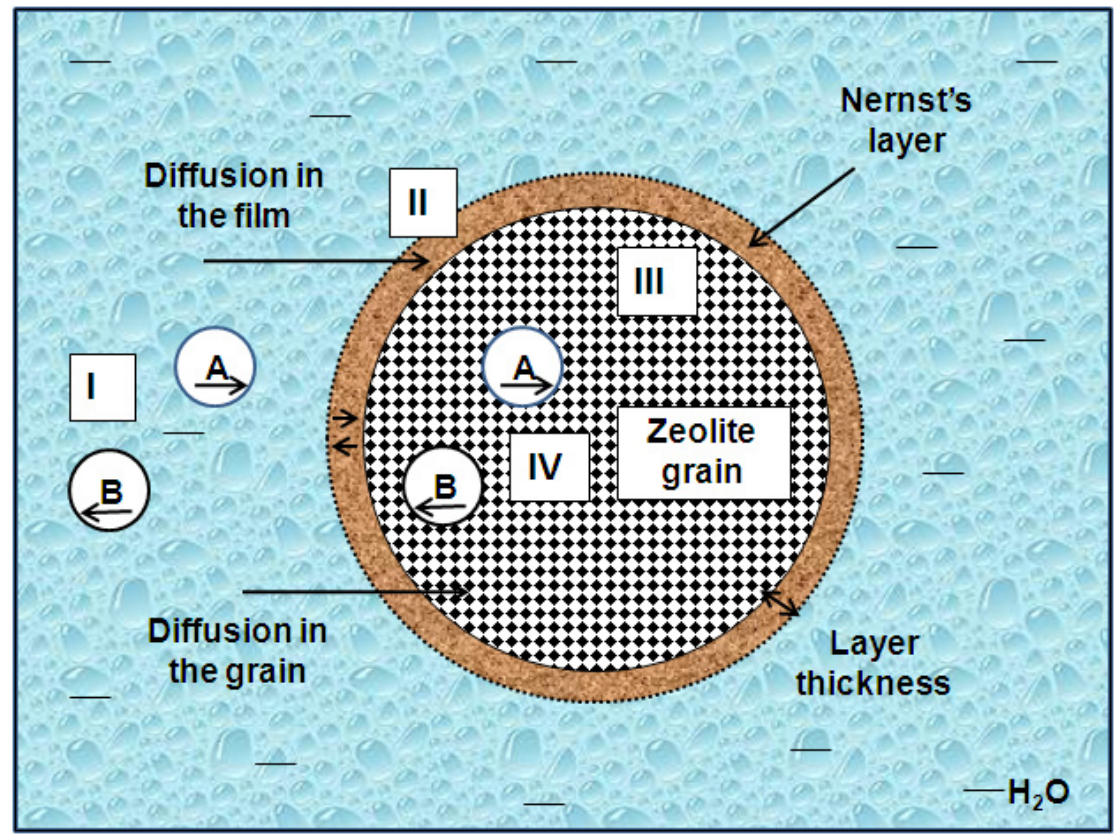

Figure 8. Diffusion processes in the system of zeolite/aqueous solution.

can be increased by intensive mixing of the solution, with increasing solution temperature and concentration. Rate of diffusion through macro and micro pores can be increased by reducing the grain size and concentration of the solution. It is therefore necessary to assess the degree of the ion-exchanging process, which is important for the overall process of ion exchange and hence affects its rate [50].

\subsection{Adsorption isotherms}

The equilibrium distribution of metal ions between the natural or modified zeolites and the solution is important in determining the maximum sorption capacity. Several isotherm models (Table 6) are available to describe the equilibrium sorption distribution. In most studies the following two models, Langmuir and Freundlich models, were used [51].

The Langmuir isotherm:

$$
q_{c}=\frac{K_{L} C_{e}}{1+Q_{\max } C_{e}}
$$

\begin{tabular}{|c|c|c|c|c|}
\hline \multirow{2}{*}{ Linear form } & \multicolumn{2}{|c|}{ Transformed } & Slope & Intercept \\
\hline & X-values & Y-values & & \\
\hline$\frac{C_{e}}{q_{e}}=\frac{1}{Q_{\max } K_{L}}+\frac{C_{e}}{Q_{\max }}$ & & $C_{e} / q_{e}$ & $Q_{\max } / K_{L}$ & $1 / K_{L}$ \\
\hline
\end{tabular}


where $q_{e}$ is metal concentration on the zeolite at equilibrium (mg of metal ion/g of zeolite); $Q_{\max }(\mathrm{mg} / \mathrm{g})$ and $K_{L}(1 / \mathrm{mg})$ are Langmuir constants related to the maximum adsorption capacity corresponding to complete coverage of available adsorption sites and a measure of adsorption energy (equilibrium adsorption constant) respectively. These constants are found from the slope and intercept of $c_{e} / q_{e}$ vs. $c_{e}$ linear plot so that $Q_{\max }=1 /$ slope and $K_{L}=$ slope/intercept.

The Freundlich isotherm:

$$
q_{e}=K_{F} C_{e}^{1 / n}
$$

\begin{tabular}{|c|c|c|c|}
\hline \multirow{2}{*}{ Linear form } & Transformed & Slope & Intercept \\
\cline { 2 - 4 } & X-values Y-values & & \\
\hline $\ln q_{e}=\ln K_{F}+\left(\frac{1}{n}\right) \ln C_{e}$ & $\ln \left(\mathrm{C}_{\mathrm{e}}\right) \quad \ln \left(\mathrm{qe}_{\mathrm{e}}\right.$ & $1 / \mathrm{n}$ & $\ln \left(\mathrm{K}_{\mathrm{F}}\right)$ \\
\hline
\end{tabular}

where $K_{F}$ and $n$ are Freundlich constants determined from the slope and intercept of plotting $\ln q_{e}$ vs. $\ln C_{e}$.

\begin{tabular}{|c|c|c|}
\hline Isotherm models & Equilibrium & Ref. \\
\hline \hline Sips & $q_{e}=\frac{q_{m}\left(a_{s} C_{e}\right)^{n_{s}}}{1+\left(a_{S} C_{e}\right)^{n_{s}}}$ & {$[52]$} \\
\hline Langmuir-Freundlich & $q_{e}=\frac{K_{L F} C_{e}^{n_{L F}}}{1+\left(a_{L F} C_{e}\right)^{n_{L F}}}$ & {$[53]$} \\
\hline Temkin & $q_{e}=\frac{R T}{b_{T}} \ln \left(A_{T} C_{e}\right)$ & {$[54]$} \\
\hline Toth & $q_{e}=\frac{K_{t} C_{e}}{\left(a_{t}+C_{e}\right)^{1 / t}}$ & {$[55]$} \\
\hline Redlich-Peterson & $q_{e}=\frac{K_{R} C_{e}}{1+a_{R} C_{e}^{b_{R}}}$ & {$[56]$} \\
\hline Dubinin-Radushkevich & $q_{e}=q_{D} \exp \left(-B_{D}\left[R T \ln \left(1+\frac{1}{C_{e}}\right)\right]^{2}\right)$ & {$[57]$} \\
\hline
\end{tabular}

Table 6. Other important isotherms models are used to describe the equilibrium sorption distribution.

\section{Gibbs free energy of sorption}

The apparent Gibbs free energy of sorption $\left(\Delta G^{0}\right)$ is the fundamental criterion of spontaneity. Reaction occurs spontaneously at a given temperature if $\Delta G^{0}$ is negative. The standard Gibbs free energy change $\left(\Delta G^{0}\right)$ for the adsorption of ions by natural or modified zeolite can be calculated using the following thermodynamic equation (7):

$$
\Delta \mathrm{G}^{0}=-\mathrm{RT} \ln \mathrm{K}
$$

where $T$ is the absolute temperature and $R$ is the gas constant $(8.314 \mathrm{~J} / \mathrm{molK})$ [44].

Table 7 shows the calculated values of Gibbs free energy for several different ions adsorbed to natural and modified zeolites 


\begin{tabular}{|c|c|c|c|}
\hline Natural zeolite & Ions & $\Delta \mathrm{G}^{0}$ & Ref. \\
\hline \hline CLI & $\mathrm{Fe}^{3+}$ & -16.98 & {$[51]$} \\
\hline Modified CLI & $\mathrm{As} \mathrm{(V)}$ & $-18,14$ & {$[58]$} \\
\hline CLI & $\mathrm{NH}_{4}{ }^{+}$ & $-19,52$ & {$[59]$} \\
\hline Modified CLI & $\mathrm{Cu}^{2+}$ & $-29,3$ & {$[60]$} \\
\hline CLI & $\mathrm{Pb}^{2+}$ & $-6,86$ & {$[61]$} \\
\hline Modified CLI & $\mathrm{Mn}^{2+}$ & $-9,8$ & {$[62]$} \\
\hline
\end{tabular}

Table 7. Gibbs free energy of sorption $\left(\Delta \mathrm{G}^{\circ}\right)$ different metal ions.

The negative sign for $\Delta G^{0}$ is indicative of the spontaneous nature of metal ions adsorption on the natural zeolite at certain temperatures.

\section{Kinetics of the adsorption process}

The kinetic results obtained from experiments can be analyzed using different kinetic models such as Lagergen pseudo first-order (8) and pseudo second-order models (9). Lagergen pseudo first-order model is given by:

$$
\ln \left(\mathrm{q}_{\mathrm{e}}-\mathrm{q}_{\mathrm{t}}\right)=\ln \mathrm{q}_{\mathrm{e}}-\mathrm{k}_{1, \text { ads }} \mathrm{t}
$$

where $q_{t}$ is metal concentration adsorbed on natural zeolite at any time (mg of metal ions/g of zeolite) and $k_{1}$ is the adsorption rate constant $\left(\mathrm{min}^{-1}\right)$. A linear plot of $\ln \left(q_{e}-q_{t}\right)$ against $t$ gives the slope $=k_{1}$ and intercept $=\ln q_{\text {e }}$.

The equation that describes the pseudo-second order model is given in the following linear form:

$$
\mathrm{t} / \mathrm{q}_{1}=1 / \mathrm{k}_{2, \mathrm{ads}} \mathrm{q}^{2}+\mathrm{t} / \mathrm{qe}_{\mathrm{e}}
$$

where $k_{2}$ is the adsorption rate constant (g/mgmin). $K_{2}$ and $q_{e}$ are found from the intercept and slop of $t / q_{t}$ vs. $t$ linear plot so that $q_{e}=1 /$ slope and $k_{2}=$ slope $2 /$ intercept.

The degree of goodness of the linear plot of these kinetic models can be judged from the value of the coefficient of determination of the plot, which can also be regarded as the criterion in the determination of adequacy of a kinetic model [51,63-64].

\section{Application efficiency of natural zeolite in water treatment}

Wastewaters obtained from processes of many industries contain pollutants (inorganic cations, anions, oils, organic matter, etc.) have a toxic effect on the ecosystem. It is necessary to treat the metal contaminated wastewater prior to discharge into the environment and the removal of these pollutants requires economically justifiable and efficient technologies and techniques [4].

Natural zeolites in wastewater treatment are quite effective in comparison with other methods. The conditions of purification process are very important for wastewater treatment. Thus possible regeneration of the zeolite, re-use of the zeolite and re-use of the 
obtained concentrate metal ions after regeneration of the zeolite, very positively impact on the environment without creating new waste. Table 8 shows the efficiency of the removal of metal cations from wastewater using natural zeolite which is supplemented with other physical and chemical methods. The efficiency of removing metal ions from wastewaters depends on many factors such as initial concentration of metal ions in wastewater, the $\mathrm{pH}$ value of the system, the possibility of formation of metal hydroxyl anion, previous chemical and thermal modification of zeolite and the amount of water that should be purified. Besides the already mentioned properties (selectivity, capacity, etc.) natural zeolites have excellent resistance to chemical, biological, mechanical or thermal changes.

\begin{tabular}{|c|c|c|c|c|c|c|c|c|c|c|c|c|}
\hline \multirow{2}{*}{\multicolumn{3}{|c|}{ Methods }} & \multicolumn{9}{|c|}{ Removal efficiency, \% } & \multirow{2}{*}{ Ref. } \\
\hline & & & \multirow{2}{*}{$\begin{array}{l}\mathrm{Cd}(\mathrm{II}) \\
96-99\end{array}$} & \multirow{2}{*}{$\begin{array}{c}\mathrm{Cr}(111) \\
99\end{array}$} & \multirow{2}{*}{$\begin{array}{c}\mathrm{Cu}(\mathrm{II}) \\
80\end{array}$} & \multirow{2}{*}{$\frac{\mathrm{Ni}(\mathrm{II})}{71-85}$} & \multirow{2}{*}{$\begin{array}{c}\mathrm{Zn}(\mathrm{II}) \\
99\end{array}$} & \multirow{2}{*}{$\begin{array}{c}\mathrm{Fe}(\mathrm{III}) \\
-\end{array}$} & \multirow{2}{*}{$\begin{array}{c}\mathrm{Mn}(\mathrm{II}) \\
99\end{array}$} & \multirow{2}{*}{$\begin{array}{c}\mathrm{Pb}(\mathrm{II}) \\
92\end{array}$} & \multirow{2}{*}{$\begin{array}{c}\mathrm{As}(\mathrm{III}) \\
-\end{array}$} & \\
\hline \multirow{6}{*}{\multicolumn{2}{|c|}{$\begin{array}{l}\text { Physical / } \\
\text { chemical } \\
\text { methods }\end{array}$}} & Precipitation & & & & & & & & & & \multirow{6}{*}{ [65-67] } \\
\hline & & lon exchange & 100 & 100 & 100 & 100 & 100 & 100 & 100 & - & - & \\
\hline & & $\begin{array}{l}\text { Membrane } \\
\text { filtration* }\end{array}$ & 93-99 & $86-95$ & $\begin{array}{l}98- \\
100\end{array}$ & $\begin{array}{l}60- \\
100\end{array}$ & $95-99$ & 90 & 85 & 99 & $20-55$ & \\
\hline & & $\begin{array}{l}\text { Coagulation/ } \\
\text { Flocculation }\end{array}$ & 99 & - & 99 & - & 99 & - & 99 & - & - & \\
\hline & & Flotation & - & 95-98 & $85-99$ & $70-98$ & $\begin{array}{l}99- \\
100\end{array}$ & - & & - & - & \\
\hline & & $\begin{array}{l}\text { Electrochem. } \\
\text { methods }\end{array}$ & 13 & $77-99$ & $98-99$ & $69-90$ & 96 & - & 78 & - & 99 & \\
\hline \multirow{5}{*}{$\begin{array}{l}\text { Natural } \\
\text { zeolite }\end{array}$} & CLI & \multirow{5}{*}{$\begin{array}{l}\text { lon exchange / } \\
\text { Adsorption }\end{array}$} & 90 & 90 & 90 & 75 & 85 & 70 & - & 95 & - & \multirow{5}{*}{ [68-75] } \\
\hline & M-CLI & & $90-99$ & 88 & 80 & 37 & 92 & 90 & 70 & 90-99 & 90 & \\
\hline & $\mathrm{CHA}$ & & - & - & 98 & 98 & 98 & - & - & - & - & \\
\hline & sco & & 59 & 96 & - & 40 & - & - & 75 & - & - & \\
\hline & PHI & & - & - & - & - & 74 & 88 & - & - & - & \\
\hline
\end{tabular}

* Membrane processes: Ultrafiltration, Nanofiltration, Reverse osmosis CLI - clinoptilolite; M-CLI modified clinoptilolite; CHA - chabazite; SCO - scolecite; PHI - philipsite

Table 8. Comparison of the efficiency removal metal ions from waste water using standard techniques and natural zeolites.

\subsection{Procedures for removing contaminants from water using natural zeolite}

Two standard procedures are usually applied to remove contaminants from water using zeolites: batch and column procedures. Before any practical ion exchange application, some specific studies of representative zeolite samples from the deposit for its exploitation potential should be carried out. The cation exchange capacity of the zeolite is distinctly dependent on its original cationic composition, because not all the cationic sites in the zeolite structure are available for cation exchange [48]. Removal efficiency of ions from water solution increases with higher portion of the main component of natural zeolite.

\subsection{1. "Batch" process}

In the batch process a certain amount of natural or modified zeolites is used, which are placed in contact with a solution of synthetic or real samples of water at certain times. Bach 
procedure is usually carried out at constant temperature and hydrodynamic conditions. The amount of immobilized ions on the zeolite is presented as equilibrium distribution of ions between the natural or modified zeolites and the solution.

The removal efficiency of metal ions by natural zeolite depends on the quantity and exchange capacity as well as the presence of other cations and anions in the treated water. With increasing concentration of metal ions in water the removal efficiency increases of these ions using natural zeolite (from $500 \mathrm{mg} / \mathrm{L}$ to $1 \mathrm{~g} / \mathrm{L}$ ). Natural and modified zeolites are efficient at low concentrations of different metal ions like $\mathrm{Zn}^{2+}$ (concentration from 1 to 5 $\mathrm{mg} / \mathrm{L}$ ) and $\mathrm{Fe}^{3+}$ (concentrations from 0.2 to $2.0 \mathrm{mg} / \mathrm{L}$ ) about $50-60 \%$. In many studies revealed the values of the maximum capacity adsorption, $\mathrm{Q}_{\max }$ for metal ions removal from synthetic and real water. On Figure $9 Q_{\max }$ values on cations uptake from water by natural zeolites from different deposits are summarized [76].

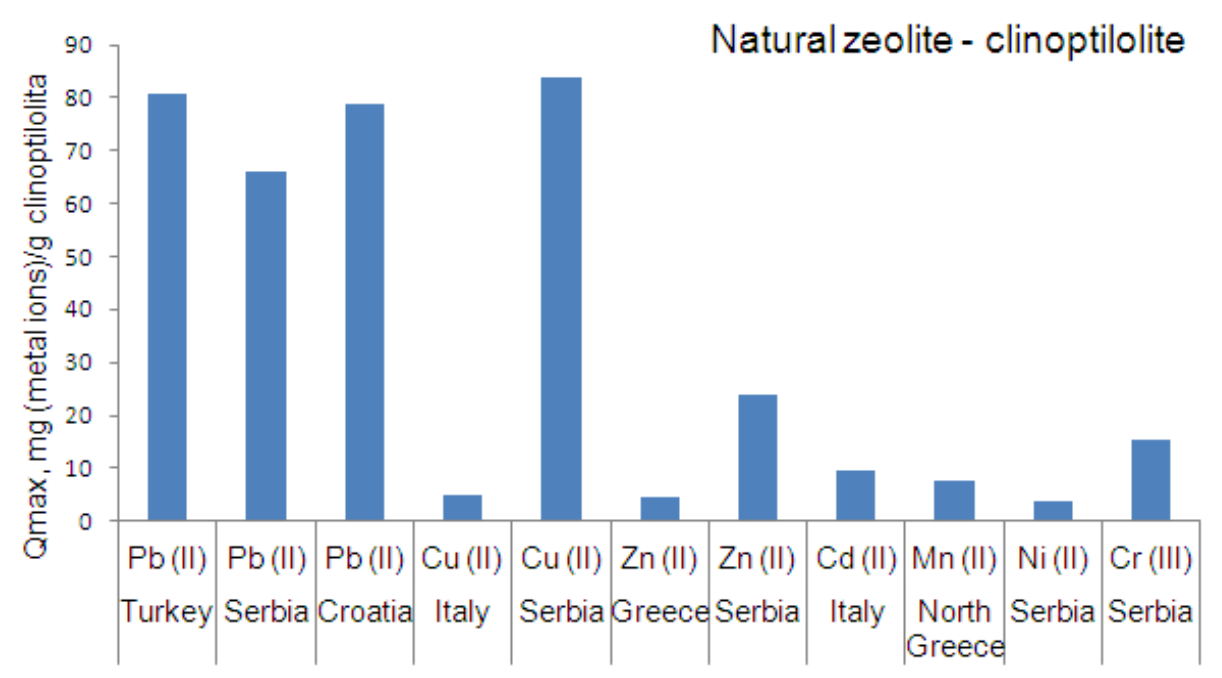

Figure 9. The uptake of some cations from water solution by natural zeolites from different deposits

Chemical pretreatment of natural zeolite (clinoptilolite) increases the removal efficiency of cations from water. The increase (in \%) in the removal efficiency for different cations by modified zeolite compared to the natural zeolite is shown in Table 9 [76]. 


\begin{tabular}{|c|c|c|c|}
\hline Zeolite & Treatment & Ion & $\begin{array}{l}\text { Increasing of removal efficiency on } \\
\text { cation uptake in relation to the natural } \\
\text { zeolite - clinoptilolite }\end{array}$ \\
\hline \multirow{11}{*}{ Clinoptilolite } & $\mathrm{NaCl}$ & \multirow{3}{*}{$\mathrm{Pb}^{2+}$} & $34 \%$ \\
\hline & $\mathrm{NaNO}_{3}$ & & $10 \%$ \\
\hline & $\mathrm{FeCl}_{3}$ & & $50 \%$ \\
\hline & $\mathrm{NaCl}$ & $\mathrm{Cu}^{2+}$ & $60 \%$ \\
\hline & $\mathrm{NaCl}$ & $\mathrm{Zn}^{2+}$ & $44 \%$ \\
\hline & $\mathrm{NaNO}_{3}$ & $\mathrm{Ni}^{2+}$ & $64 \%$ \\
\hline & $\mathrm{NaCl}$ & \multirow{2}{*}{$\mathrm{Cd}^{2+}$} & $33 \%$ \\
\hline & $\mathrm{NaNO}_{3}$ & & $34 \%$ \\
\hline & $\mathrm{NaCl}$ and $\mathrm{NaOH}$ & \multirow{2}{*}{$\mathrm{NH}_{4}{ }^{+}$} & $45 \%$ \\
\hline & $\mathrm{NaCl}$ & & $33 \%$ \\
\hline & $\mathrm{KOH}$ and $\mathrm{Fe}\left(\mathrm{NO}_{3}\right)_{3}$ & $\mathrm{Mn}^{2+}$ & $71 \%$ \\
\hline
\end{tabular}

Table 9. Effect of chemical pretreatment on the removal efficiency of cations by natural zeolite clinoptilolite.

For efficient water treatment an important property of natural zeolite is regeneration through cyclic processes and their re-use. Recent studies of desorption efficiency of metal ions and regeneration natural zeolite - clinoptilolite are presented in Table 10 and indicate that the process is reversible in most cases [77].

\begin{tabular}{|c|c|c|}
\hline Metal ion & Desorbing solution & Desorption efficiency, $\%$ \\
\hline \multirow{2}{*}{$\mathrm{Pb}^{2+}$} & $3 \mathrm{M} \mathrm{KCl}$ & $>99,5$ \\
\cline { 2 - 3 } & $0,5 \mathrm{M} \mathrm{NaCl}$ & 95 \\
\hline \multirow{2}{*}{$\mathrm{Zn}^{2+}$} & $0,34 \mathrm{NaCl}$ & 24 \\
\cline { 2 - 3 } & $5 \mathrm{~g} / \mathrm{L} \mathrm{EDTA}$ & 29 \\
\hline \multirow{2}{*}{$\mathrm{Cd}^{2+}$} & $1 \mathrm{M} \mathrm{KNO} 3$ & 92 \\
\cline { 2 - 3 } & $1 \mathrm{M} \mathrm{NaCl}$ & 97 \\
\hline \multirow{2}{*}{$\mathrm{Cu}^{2+}$} & $0,34 \mathrm{NaCl}$ & 20 \\
\hline & $5 \mathrm{~g} / \mathrm{LDTA}$ & 60 \\
\hline $\mathrm{Ni}^{2+}$ & $0,1 \mathrm{M} \mathrm{HCl}$ & 93 \\
\hline
\end{tabular}

Table 10. Desorption efficiency of metal ions and regeneration natural zeolite-clinoptilolite.

Sorption of ions on to iron modified natural zeolite depends on the success of chemical modification and creation of iron hydroxide on its surface. Effect of solution $\mathrm{pH}$ and initial concentration of arsenic ions in water are very important for removal efficiency of arsenic ions [7, 44]. The sorption efficiency of arsenic ions on to iron modified zeolite (Serbia) decreases in the order: $\mathrm{Pb}$ (II) $>\mathrm{As}(\mathrm{V})>\mathrm{Mn}$ (II) $>\mathrm{As}$ (III) $\geq \mathrm{Cr}$ (VI) (Figure 10 (left). With increasing initial concentration of As $(\mathrm{V})$ ions removal efficiency of As (V) ions decreases continuously with the use of natural zeolites from deposit D.Jesenje (Croatia) and V. Banja (Serbia). Also, at higher initial concentration of arsenic ions (300 mg/L) removal efficiency of 
As (V) ions is $30 \%$ lower for natural zeolite (Croatia) in relation to the natural zeolite (Serbia) (Figure 10 (right)).
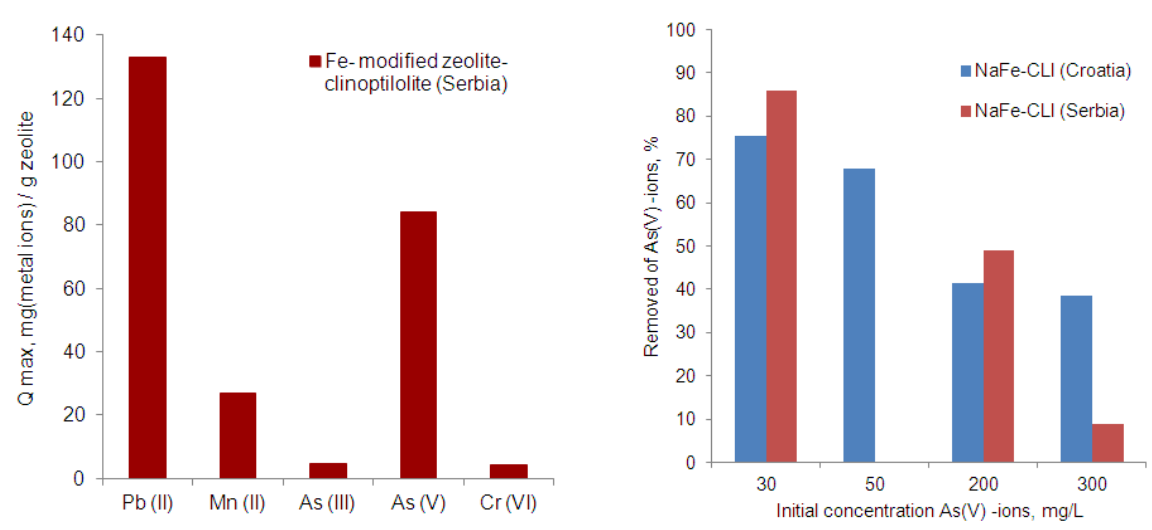

Figure 10. Sorption efficienty of ions on to iron modified zeolite - clinoptilolite

On the other hand, several anions (e.g. acetate, chloride, nitrate, phosphate or sulphate) have been witnessed as interfering with arsenate sorption. For arsenic ions binding on iron modified zeolite, the process was irreversible, i.e. stable complexes of arsenic and iron occurred, which is very important for permanent removal of arsenic ions from water solutions.

Ammonium is one of the main pollutants contained in municipal sewage, fertiliser factory wastewater and agricultural wastes. Although non-toxic, it is dangerous for the environment being one of the main causes of eutrophication. Cation-exchange has been identified as the $\mathrm{NH}_{4}{ }^{+}$sorption mechanism with operating CEC values comprised from 0.1 to $2.3 \mathrm{meq} / \mathrm{g}$ (from 1.8 to $41.4 \mathrm{mg} / \mathrm{g}$ ). Specifically, the highest values have been registered for sodium-exchanged clinoptilolite. Some studies have shown that ammonium ions bind on the zeolite framework through the combination of two parallel processes: ion exchange and adsorption. Zeolite modification by $\mathrm{NH}_{4}{ }^{+}$ions is established by increasing ammonium ion concentrations and is determined by cation exchange capacity and concentrations of metal ions released from zeolite structure. $\mathrm{Na}^{+}$ion is most rapidly exchanged with ammonium ions from water solutions. Total CEC of zeolite was found to be up to $13 \mathrm{mg} \mathrm{NH} 4^{+} / \mathrm{g}$ zeolite (deposit D. Jesenje, Croatia). Chemical treatment of natural zeolite with different concentrations of $\mathrm{HCl}$ has a significant influence on ammonium ion removal from solutions. Namely, the higher the acid concentration with which zeolite is treated, the weaker is the exchange capacity for $\mathrm{NH}_{4}{ }^{+}$ions (Figure 11) [78].

Anions as well as in-dissociated or poorly dissociated compounds, both inorganic and organic (e.g. cyanide, flouride, borate, hydrocarbon derivatives) are noxious contaminants present in water mainly as a consequence of chemical-intensive industry or are of natural origin. Two main modifications have been noticed to make zeolites effective also for sorption of these species: i) metal doping and ii) treatment with cationic organic surfactants. 


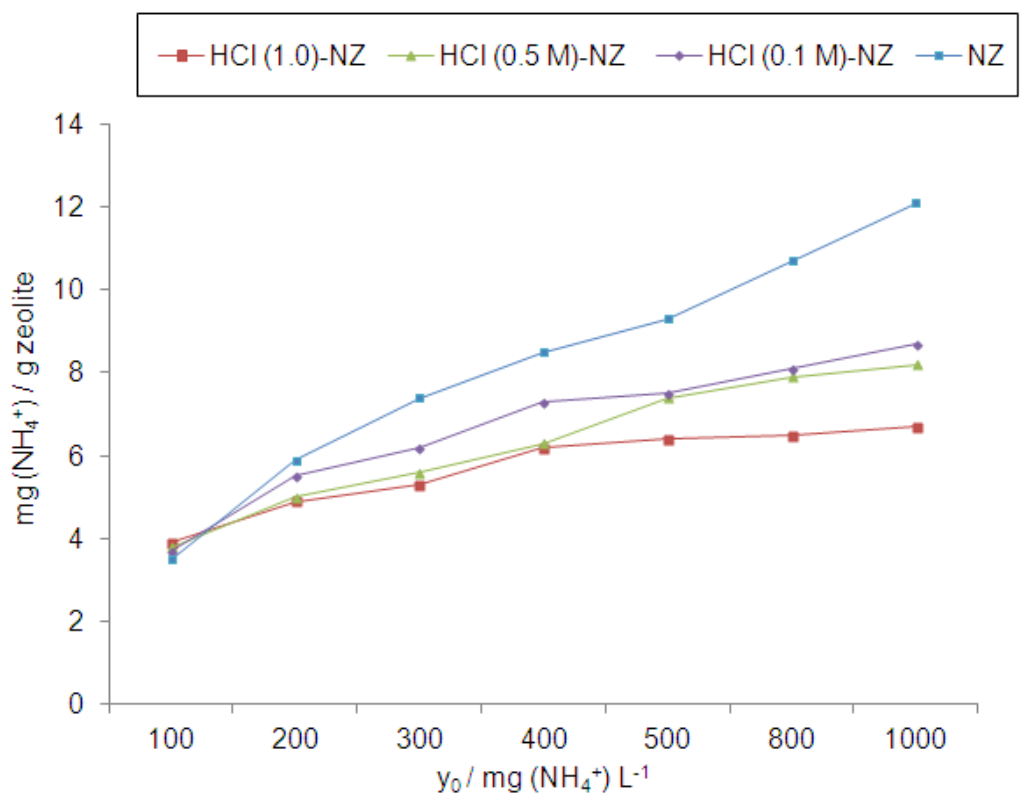

Figure 11. Removal of $\mathrm{NH}_{4}{ }^{+}$-ion from solution using chemicaly treated natural zeolite with different concentrations of $\mathrm{HCl}$.

In spite of that, clinoptilolite mineral as such has been surprisingly reported as sorbent for the removal of naturally occurring fluoride from well water Fluoride removal efficiency higher than $50 \%$ (from 2 to $6 \mathrm{mg} / \mathrm{L}$ initial fluoride concentration) has been claimed. Metal doping (e.g. addition of oxides of lanthanides, aluminium or zirconium) has been cited as a possible way to improve natural zeolite removal efficiency. Two mechanisms have been inferred for fluoride sorption: hydroxide/fluoride exchange (due to steric and electrostatic similarities between these anions) [61] and fluoride occlusion [79].

\subsubsection{Column process}

In the column process there are several aspects that affect the dynamics of the cation uptake by zeolite, such factors are mainly solution (temperature, $\mathrm{pH}$, the flow rate, the initial cation concentration being removed by zeolite, the pretreatment solution, the presence of other competing ions in the solution, characteristics of the heavy metal being removed by the zeolite) and solid specific factors (particle size, surface dust, impurities found in the zeolite sample, the pretreatment procedure type applied to the zeolite). Results of examinations in the column procedure are presented by breakthrough curves [80,81]. In Table 11 shown the removal efficiency of cations from different polluted water in column process. 


\begin{tabular}{|c|c|c|c|c|c|}
\hline Zeolite/Water & Process conditions & Ion & Removal efficiency & Regeneration & Ref. \\
\hline $\begin{array}{l}\text { Clinoptilolite } \\
\text { (USA) } \\
\text { wastewater }\end{array}$ & $\begin{array}{l}\mathrm{pH} 6,5 \\
\text { two zeolite columns } \\
\text { in series }\end{array}$ & $\mathrm{NH}_{4}^{+}$ & $99 \%$ & $\mathrm{NaCl}, \mathrm{CaCl}_{2}$ & [82] \\
\hline $\begin{array}{l}\text { Clinoptilolite } \\
\text { (USA) } \\
\text { municipal } \\
\text { wastewaters }\end{array}$ & $\begin{array}{l}\mathrm{pH} 4-8 \\
\text { Different particle size } \\
\text { from } 0.3 \text { to } 0.84 \mathrm{~mm} \\
\text { Flow rate } 15 \mathrm{BV} / \mathrm{h} .\end{array}$ & $\mathrm{NH}_{4}^{+}$ & $95.7 \%$ & $\begin{array}{c}\mathrm{NaCl}, \mathrm{NaOH} \\
\mathrm{CaCl}_{2}\end{array}$ & [83] \\
\hline $\begin{array}{c}\text { Clinoptilolite } \\
\text { (Turkey) }\end{array}$ & $\begin{array}{l}\text { Different particle size } \\
\text { from } 0,3 \text { to } 3,35 \mathrm{~mm} \\
\text { Flow rates } 22-78 \mathrm{BV} / \mathrm{h}\end{array}$ & $\mathrm{NH}_{4}^{+}$ & $\begin{array}{l}{ }^{*} \mathrm{QB}=0,085-0,891 \\
\text { meq } \mathrm{NH}_{4}{ }^{+} / \mathrm{g} \text { zeolite }\end{array}$ & - & [84] \\
\hline $\begin{array}{c}\text { Clinoptilolite } \\
\text { (Turkey) }\end{array}$ & $\begin{array}{l}\text { Different particle size } \\
\text { from } 0.3 \text { to } 0.6 \mathrm{~mm}\end{array}$ & $\begin{array}{l}\mathrm{NH}_{4}^{+}, \\
\mathrm{Cs}^{+}\end{array}$ & $\begin{array}{l}{ }^{*} \mathrm{QB}=0.036-1.08 \\
\text { meq } \mathrm{NH}_{4}{ }^{+} / \mathrm{g} \text { zeolite }\end{array}$ & - & [85] \\
\hline $\begin{array}{c}\text { Clinoptilolite } \\
\text { (Cuba) } \\
\text { piggery manure } \\
\text { wastewater }\end{array}$ & $\begin{array}{l}\text { Particle size - } 5 \mathrm{~mm} \\
\text { Modified zeolite with } \\
\mathrm{NaCl}, \mathrm{KCl}, \mathrm{CaCl}_{2}, \mathrm{MgCl}_{2}\end{array}$ & $\mathrm{NH}_{4}^{+}$ & $90 \%$ & - & {$[86]$} \\
\hline $\begin{array}{c}\text { Clinoptilolite, } \\
\text { Mordenite } \\
\text { (New Zealand) } \\
\text { wastewater }\end{array}$ & $\begin{array}{l}\text { Different particle size } \\
\text { from } 0,25 \text { to } 2,83 \mathrm{~mm}\end{array}$ & $\mathrm{NH}_{4}^{+}$ & $\begin{array}{c}95 \% \text { (Clinoptilolite) } \\
55 \% \text { (Mordenite) }\end{array}$ & - & [87] \\
\hline $\begin{array}{c}\text { Phillipsite, } \\
\text { Chabazite } \\
\text { (Spain, Israel) } \\
\text { wastewater }\end{array}$ & $\begin{array}{l}\text { Flow rate } 0,35 \mathrm{~mL} / \mathrm{min} \\
\text { Flow rate } 27 \mathrm{BV} / \mathrm{h}\end{array}$ & $\mathrm{NH}_{4}^{+}$ & $\begin{array}{l}82 \% \text { (Phillipsite/ } \\
\text { Chabazite) } \\
95 \% \text { (Chabazite) }\end{array}$ & - & {$[88,89]$} \\
\hline $\begin{array}{c}\text { Clinoptilolite } \\
\text { (USA) } \\
\text { battery } \\
\text { manufacturing } \\
\text { wastewater } \\
\end{array}$ & $\begin{array}{l}\mathrm{pH}(5,5-6) \\
\text { Different particle size } \\
\text { from } 0.2 \text { to } 0.5 \mathrm{~mm} \\
\text { Modified zeolite with } \mathrm{NaCl} \\
\text { Flow rate } 10 \mathrm{BV} / \mathrm{h}\end{array}$ & $\mathrm{Pb}^{2+}$ & $\approx 90 \%$ & $\mathrm{NaCl}$ & [90] \\
\hline $\begin{array}{l}\text { Clinoptilolite } \\
\text { (Slovakia) } \\
\text { drinking water }\end{array}$ & $\begin{array}{l}\text { Different particle size } \\
\text { from } 3 \text { to } 5 \mathrm{~mm} \\
\text { Thermaly treated } \\
\text { clinoptilolite }\end{array}$ & $\mathrm{NH}_{4}^{+}$ & $20 \%-40 \%$ & $\mathrm{NaCl}$ & [91] \\
\hline $\begin{array}{c}\text { Clinoptilolite } \\
\text { (Turkey) }\end{array}$ & $\begin{array}{l}\text { Different particle size } \\
\text { from } 0,875 \text { to } 2,0 \mathrm{~mm} \\
\text { Flow rates } 10,25,50, \\
75 \mathrm{BV} / \mathrm{h}\end{array}$ & $\mathrm{NH}_{4}{ }^{+}$, & $\begin{array}{c}{ }^{*} \mathrm{QB}=0,57 \mathrm{meq} / \mathrm{g} \\
\text { zeolita (smaller } \\
\text { particle size) } \\
{ }^{*} \mathrm{QB}=0,38 \mathrm{meq} / \mathrm{g} \\
\text { zeolita (larger } \\
\text { particle size) }\end{array}$ & - & [92] \\
\hline
\end{tabular}

\begin{tabular}{|c|c|c|c|c|c|}
\hline Zeolite/Water & Process conditions & Ion & Removal efficiency & Regeneration & Ref. \\
\hline $\begin{array}{c}\text { Clinoptilolite } \\
\text { (Greece) }\end{array}$ & $\begin{array}{l}\text { Different particle size } \\
\text { from } 1,14 \text { to } 1,18 \mathrm{~mm} \\
\text { Flow rates } 5,10,15 \mathrm{BV} / \mathrm{h}\end{array}$ & $\begin{array}{l}\mathrm{Pb}^{2+} \\
\mathrm{Cr}^{3+} \\
\mathrm{Fe}^{3+} \\
\mathrm{Cu}^{2+}\end{array}$ & $\begin{array}{c}{ }^{*} \mathrm{QB}= \\
0.433 \mathrm{meq} \mathrm{Pb}^{2+} / \\
\text { g zeolite }\end{array}$ & - & [93] \\
\hline $\begin{array}{l}\text { Clinoptilolite } \\
\text { (Greece) } \\
\text { groundwater }\end{array}$ & $\begin{array}{l}\text { Different particle size } \\
\text { from } 0,15 \text { to } 1 \mathrm{~mm}\end{array}$ & \begin{tabular}{|c|}
$\mathrm{NH}_{4}{ }^{+}$ \\
$\mathrm{Cu}^{2+}, \mathrm{Pb}^{2}$ \\
+ \\
\end{tabular} & $82 \%\left(\right.$ except $\mathrm{Cu}^{2+}$ ion $)$ & - & [94] \\
\hline $\begin{array}{c}\text { Clinoptilolite, } \\
\text { (New Zealand) } \\
\text { wastewater }\end{array}$ & - & $\mathrm{NH}_{4}^{+}$ & $\begin{array}{c}{ }^{*} \mathrm{QB}=18.7-20.1 \mathrm{~g} \\
\mathrm{NH}_{4}{ }^{+} / \mathrm{kg} \text { zeolite }\end{array}$ & $\mathrm{HCl}$ & [95] \\
\hline $\begin{array}{l}\text { Clinoptilolite } \\
\text { (Turkey) } \\
\text { drinking water }\end{array}$ & $\begin{array}{l}\text { Different particle size } \\
\text { from } 1 \text { to } 2,8 \mathrm{~mm}\end{array}$ & $\mathrm{NH}_{4}^{+}$ & - & $\mathrm{NaCl}, \mathrm{NaOH}$ & [96] \\
\hline $\begin{array}{l}\text { Clinoptilolite } \\
\text { (Iran) } \\
\text { wastewater }\end{array}$ & $\begin{array}{l}\text { Different particle size } \\
\text { from } 0,42 \text { to } 0,84 \mathrm{~mm}\end{array}$ & $\mathrm{NH}_{4}^{+}$ & $\begin{array}{c}{ }^{*} \mathrm{QB}=16.31-19,5 \mathrm{mg} \\
\mathrm{NH}_{4}{ }^{+} / \mathrm{g} \text { zeolita }\end{array}$ & $\mathrm{NaCl}$ & [97] \\
\hline $\begin{array}{l}\text { Clinoptilolite } \\
\text { (Turkey) } \\
\text { municipal } \\
\text { wastewater }\end{array}$ & $\begin{array}{l}\text { Different particle size } \\
\text { from } 1 \text { to } 2 \mathrm{~mm} \\
\text { Flow rate } 0.5 \mathrm{~mL} / \mathrm{min}\end{array}$ & $\mathrm{NH}_{4}^{+}$ & $\begin{array}{c}{ }^{*} \mathrm{QB}=1,646 \text { meq } \mathrm{NH}_{4}{ }^{+} / \\
\text {g zeolita }\end{array}$ & - & [98] \\
\hline $\begin{array}{l}\text { Clinoptilolite } \\
\text { (Serbia) }\end{array}$ & $\begin{array}{l}\text { Different particle size } \\
\text { from } 0,6 \text { to } 0,8 \mathrm{~mm} \\
\text { Flow rates } 1,2,3 \mathrm{~mL} / \mathrm{min}\end{array}$ & $\mathrm{Pb}^{2+}$ & $96 \%$ & - & {$[99,100]$} \\
\hline $\begin{array}{c}\text { Clinoptilolite, } \\
\text { mordenit } \\
\text { (New Zealand) } \\
\text { wastewater }\end{array}$ & $\begin{array}{l}\text { Different particle size } \\
\text { from } 0,5 \text { to } 1,4 \mathrm{~mm} \\
\text { Modified zeolite with } \mathrm{NaCl}\end{array}$ & $\mathrm{NH}_{4}^{+}$ & $\begin{array}{l}50 \% \text { (Clinoptilolite) } \\
36 \% \text { (Mordenite) }\end{array}$ & - & [101] \\
\hline $\begin{array}{l}\text { Clinoptilolite } \\
\text { (Croatia and } \\
\text { Serbia) } \\
\text { ground water }\end{array}$ & $\begin{array}{l}\text { Particle size }<63 \mu \mathrm{m} \\
\text { Flow rate } 420 \mathrm{~L} / \mathrm{h} \\
\text { Modified zeolite with } \mathrm{NaCl}\end{array}$ & $\mathrm{NH}_{4}^{+}$ & $99-100 \%$ & $\mathrm{NaCl}$ & [102] \\
\hline $\begin{array}{l}\text { Clinoptilolite } \\
\text { (China) }\end{array}$ & $\begin{array}{l}\text { Different particle size } \\
\text { from } 52 \text { to } 61 \mu \mathrm{m}\end{array}$ & $\mathrm{Pb}^{2+}$ & $\begin{array}{c}{ }^{*} \mathrm{QB}=\mathrm{mg} \mathrm{Pb} 2+/ \mathrm{g} \\
\text { zeolite }\end{array}$ & - & [103] \\
\hline
\end{tabular}

Table 11. The removal efficiency of cations in column process $\left({ }^{*} \mathrm{QB}\right.$ - breakthrough capacity) 
Two examples from the Eastern Croatia show a successful application of research results at a pilot plant for potable water. The ground water from the Valpovo region was previously treated by aeration and sand filtration for the removal of iron, manganese, ammonium and other present pollutants. The physical and chemical parameters of the ground water and ammonium concentration were determined in the ground water after the pre-treatment. The ammonium sorption efficiency of $100 \%$ was obtained after 10 to $90 \mathrm{~h}$ with the use of MNZ$\mathrm{SRB}$, but it was sharply decreased after $70 \mathrm{~h}$ with use of NZ-CRO or MNZ-CRO (Figure 12).

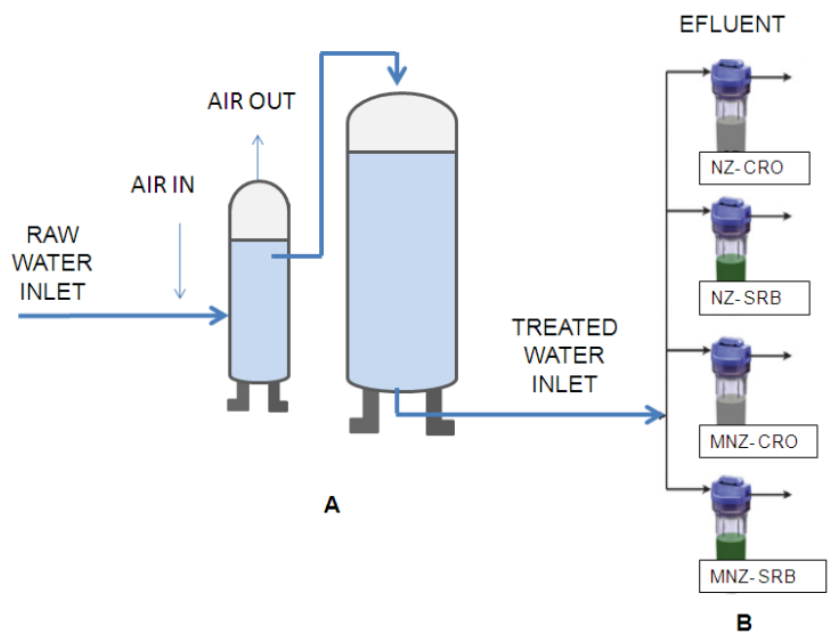

Figure 12. Scheme of drinking water production plant (A) and pilot plant "filter guards" (B) (NZ-, MNZ-CRO natural and modified zeolite from Croatia; NZ-, MNZ-SRB natural and modified zeolite from Serbia) [102].

Natural zeolite modification was carried out by applying a manganese dioxide layer, which is a technologically protected/patented procedure. Obtained results have shown that the removal efficiency of iron ions from drinking water can be increased by about $90 \%$ by using modified zeolite.

The $\mathrm{MnO}_{2}$-modified clinoptilolite (New Mexico, USA) appears to be a promising adsorbent for removing trace arsenic amounts from water. The removal efficiency obtained with the modified zeolite was doubled as compared to that obtained with the unmodified zeolite [30].

\section{Conclusions}

The unique ion exchange and adsorption properties, high porosity and excellent thermal stability of zeolites make them very suitable for many applications, also in water treatment processes. Many different studies have demonstrated their effectiveness in reducing the concentrations of contaminants (heavy metals, anions and organic matter) in water. The complexity of aquatic systems demands special attention in the selection and preparation of 
materials for water purification. The chemical behavior of natural zeolites in different aqueous environments, which was also a subject of recent geochemical and technological studies, additionally proved their applicability, although monitoring of $\mathrm{pH}$ and its changes, remains very important for their use of real environments. Namely, zeolites can interact with hydrogen or hydroxyl ions present in solutions and, as a consequence, certain physicochemical phenomena such as hydrolysis of solids, degradation, dissolution and even phase transformations can occur. All these phenomena again depend on the structural characteristics and the chemical composition of the used zeolite. Nowadays, modified natural zeolites are increasingly used also for biological treatment of water, precisely for surface binding of biological agents from water. Further research should be focused on the optimization of the surface modification procedures to raise their efficiency and to enhance the capability of regeneration. Furthermore, detailed characterization of natural and modified zeolites is needed to better understand the structure-property relationship. To open up new possibilities for their application, the possible further uses of used zeolites as well as the behavior of zeolites at extreme conditions, also at low temperatures, should be examined.

\section{Author details}

Karmen Margeta

University of Zagreb, Faculty of Chemical Engineering and Technology, Croatia

Nataša Zabukovec Logar

National Institute of Chemistry, Ljubljana, Slovenia

Mario Šiljeg

Croatian Environment Agency, Zagreb, Croatia

Anamarija Farkaš

Institute for International Relations, Zagreb, Croatia

\section{Acknowledgment}

The work described in the chapter was partly supported by the Ministry of Science, Education and Sports of the Republic of Croatia through the research project 125-12530923004, by the Ministry of Science, Education and Sports of the Republic of Croatia through the bilateral project (Croatia-Slovenia) "Natural zeolite in water nanotechnology", by the Slovenian Research Agency research program P1-0021, and by the EUREKA E!4208 project "PUREWATER". The financial support from the founding agencies as well as the scientific contribution of researchers involved in the projects is greatly acknowledged.

\section{References}

[1] Caputo D, Pepe F (2007) Experiments and data processing of ion exchange equilibria involving Italian natural zeolites: a review. Micropor.Mesopor.Mater. 105:222-231. 
[2] Misaelides P (2011) Application of natural zeolites in environmental remediation: A short review. Micropor.Mesopor.Mater. 144:15-18.

[3] Fu F, Wang Q (2011) Removal of heavy metal ions from wastewaters: A review. J.Environ.Manage.92:407-418.

[4] Wang S, Peng Y (2010) Natural zeolites as effective adsorbents in water and wastewater treatment. Chem. Engin.J. 156:11-24.

[5] Moussavia G, Talebi S, Farrokhi M, Sabouti RM (2011) The investigation of mechanism, kinetic and isotherm of ammonia and humic acid co-adsorption onto natural zeolite. Chem. Engin.J. 171:1159-1169.

[6] Inglezakis VJ, Doula MK, Aggelatou V, Zorpas AA (2010) Removal of iron and manganese from underground water by use of natural minerals in batch mode treatment. Desalin. Water Treat. 18:341-346.

[7] Doula MK (2009) Simultaneous removal of $\mathrm{Cu}, \mathrm{Mn}$ and $\mathrm{Zn}$ from drinking water with the use of clinoptilolite and its Fe-modified form. Water Res. 43:15:3659-3672.

[8] Li Z, Jean JS, Jiang WT, Chang PH, Chen CJ, Liao L (2011) Removal of arsenic from water using Fe-exchanged natural zeolite. J.Hazard. Mater. 187:318-323.

[9] Habuda-Stanić M, Kalajdžić B, Kuleš M, Velić N (2008) Arsenite and arsenate sorption by hydrous ferric oxide/polymeric material. Desalination 229:1-9.

[10] Doula MK, Dimirkou A (2008) Use of an iron-overexchanged clinoptilolite for the removal of $\mathrm{Cu} 2+$ ions from heavily contaminated drinking water samples. J.Hazard. Mater. 151:2-3:738-745.

[11] Mohapatra M, Anand S, Mishra BK, Giles DE, Singh P (2009) Review of fluoride removal from drinking water. J.Environ.Manage. 91:67-77.

[12] Bhatnagar A, Sillanpaa M (2011) A review of emerging adsorbents for nitrate removal from water. Chem. Engin. J. 168:493-504.

[13] Widiastuti N, Wu H, Ming Ang H, Zhang D (2011) Removal of ammonium from grey water using natural zeolite, Desalination 277:15-23.

[14] Widiastuti N, Wu H, Ming Ang H, Zhang D (2008) The potential application of natural zeolite for greywater treatment, Desalination 218:271-280.

[15] Margeta K, Vojnović B, Zabukovec Logar N (2011) Development of natural zeolites for their use in water-treatment systems. Recent patents of nanotech. 5:2:89-99.

[16] Breck DW (1974) Zeolite molekular sieves, John.Wiley\&Sons, New York

[17] Baerlocher Ch, McCusker LB, Olson DH (2007) Atlas of Zeolite Framwork, Sixth Revised Edition, Elsavier, Netherlands.

[18] Farkaš A, Rožić M, Barbarić-Mikočević Ž (2005) Ammonium exchange in leakage waters of waste dumps using natural zeolite from the Krapina region, Croatia. J.Hazard.Mater. 117:1:25-33.

[19] Š. Cerjan-Stefanović, N. Zabukovec Logar, K. Margeta, N. Novak Tušar, I. Arčon; K. Maver, J. Kovač, V. Kaučič (2007) Structural investigation of Zn2+ sorption on clinoptilolite tuff from the Vranjska Banja deposit in Serbia. Micropor. Mesopor.Mater. 105:3:251-259.

[20] Wang S, Zhub ZH (2006) Characterisation and environmental application of an Australian natural zeolite for basic dye removal from aqueous solution. J.Hazard.Mater. 136:946-952. 
[21] Davila-Jimenez MM, Elizalde-Gonzalez MP, Mattusch J, Morgenstern P, Perez-Cruz MA, Reyes-Ortega Y., Wennrich R, Yee-Madeira H (2008) In situ and ex situ study of the enhanced modification with iro of clinoptilolite-rich zeolitic tuff for arsenic sorption from aqueous solutions. J.Colloid.Interf.Sci. 322:527-536.

[22] Liang Z, Ni J (2009) Improving the ammonium ion uptake onto natural zeolite by using as integrated modification process. J.Hazard.Mater. 166:52-60.

[23] Coruh S, Senel G, Nuri Ergun O (2010) A comparison of the properties of natural clinoptilolites and their ion-exchange capacities for silver removal. J.Hazard.Mater. 180:486-492.

[24] Farías T, Ruiz-Salvador AR, Velazco L, Charles de Ménorval L, Rivera A (2009) Preparation of natural zeolitic supports for potential biomedical applications. Mater.Chem.Phy.118:322-328.

[25] Allen SJ, Ivanova E, Koumanova B (2009) Adsorption of sulfur dioxide on chemically modified natural clinoptilolite. Acid modification, Chem.Engin.J. 152:389-395.

[26] Filippidis A, Kantiranis N (2007) Experimental neutralization of lake and stream waters from N. Greece using domestic HEU-type rich natural zeolitic material. Desalination, 213:47-55.

[27] Sprynsky M, Golembiewski R, Trykowski G, Buszewski B (2010) Heterogeneity and hierarchy of clinoptilolite porosity. J.Phy.Chem.Solids, 71:1269-1277.

[28] Calvo B, Canoira L, Morante F, Martínez-Bedia JM, Vinagre C, García-González JE, Elsen J, Alcantara R (2009) Continuous elimination of $\mathrm{Pb} 2+, \mathrm{Cu} 2+, \mathrm{Zn} 2+, \mathrm{H}+$ and NH4+ from acidic waters by ionic exchange on natural zeolite. J.Hazard.Mater. 166:2-3:619627.

[29] Ruggieri F, Marín V, Gimeno D, Fernandez-Turiel JL, García-Valles M, Gutierrez L (2008) Application of zeolitic volcanic rocks for arsenic removal from water. Engineering Geology. 101:3-4: 245-250.

[30] Camachoa LM, Parrab RR, Denga Sh (2011) Arsenic removal from groundwater by MnO2-modified natural clinoptilolite zeolite: Effects of $\mathrm{pH}$ and initial feed concentration. J.Hazard.Mater. 189:286-293.

[31] Kumar Jha V, Hayashi Sh (2009) Modification on natural clinoptilolite zeolite for its $\mathrm{NH}^{4+}$ retention capacity. J.Hazard.Mater. 169:1-3:29-35.

[32] Oliveira CR, Rubio J (2007) New basis for adsorption of ionic pollutants onto modified zeolites. Mineral. Engin. 20:6:552-558.

[33] Ortega EA, Cheeseman Ch, Knight J, Loizidou M (2000) Properties of alkali-activated clinoptilolite. Cement.Concrete.Res. 30:10:1641-1646.

[34] Dávila-Jiménez MM, Elizalde-González MP, Mattusch J, Morgenstern P, Pérez-Cruz MA, Reyes-Ortega Y, Wennrich R, Yee-Madeira H (2008) In situ and ex situ study of the enhanced modification with iron of clinoptilolite-rich zeolitic tuff for arsenic sorption from aqueous solutions. J.Colloid.Interf. Sci. 322:2:527-536.

[35] Šiljeg M, Cerjan Stefanović Š, Mazaj M, Novak Tušar N, Arčon I, Kovač J, Margeta K, Kaučič V, Zabukovec Logar N (2009) Structure investigation of As(III)- and As(V)species bound to Fe-modified clinoptilolite tuffs, Micropor. Mesopor.Mater. 118:1-3:408415. 
[36] Jeon CS, Baek K, Park JK, Oh YK, Lee SD (2009) Adsorption characteristics of As(V) on iron-coated zeolite. J.Hazard.Mater. 163:2-3:804-808.

[37] Chutia P, Kato S, Kojima T, Satokawa S (2009) Adsorption of As(V) on surfactantmodified natural Zeolites. J.Hazard.Mater. 162:1:204-211.

[38] Li Z, Kirk Jones H, Zhang P, Bowman RS (2007) Chromate transport through columns packed with surfactant-modified zeolite/zero valent iron pellets. Chemosphere 68:18611866.

[39] Stefanakis AI, Akratos CS, Gikas GD, Tsihrintzis VA (2009) Effluent quality improvement of two pilot-scale, horizontal subsurface flow constructed wetlands using natural zeolite. Micropor.Mesopor.Mater. 124:1-3:131-143.

[40] Bosinceanu R, Sulitanu N. (2008) Synthesis and characterization of $\mathrm{FeO}(\mathrm{OH}) / \mathrm{Fe} 3 \mathrm{O} 4$ nanoparticles encapsulated in zeolite matrix, J. Optoelectron. Advanc. Mater. 10:34823486.

[41] Rožić M., Miljanic S (2011) Sorption of HDTMA cations on Croatian natural mordenite tuff. J.Hazard.Mater. 185:1:423-429.

[42] Grossal PR, Eick MJ, Sparks DL, Goldberg S, Ainsworth CC (1997) Environ.Sci.Techol. 31:321-326.

[43] Fenforf S, Eick MJ, Grossal PR, Sparks DL (1997) Environ. Sci. Technol, 31: 315-320.

[44] Kragović M, Daković A, Sekulić Ž, Trgo M, Ugrina M, Perić J, Gatta GD (2012) Removal of lead from aqueous solution by using the natural and Fe(III) modified zeolite. Appl.Surf.Sci. 258:8:3667-3673.

[45] Rozić M, Cerjan-Stefanović Š, Kurajica S, Mačefat M, Margeta K, Farkaš A (2005) Decationization and dealumination of clinoptilolite tuff andammonium exchange on acid-modified tuff. J. Colloid Interf. Sci. 284:1:48-56.

[46] Inglezakis VJ (2005) The concept of "capacity" in zeolite ion-exchange systems. J.Colloid Interf. Sci. 281:68-79.

[47] Armbruster T (2001) Clinoptilolite-heulandite:applications and basic research. Stud.Surf.Sci.Cataly. 135:13-27.

[48] Langella A, Pansini M, Cappelletti P, de Gennaro B, de Gennaro M, C. Colella (2000) $\mathrm{NH}^{4+}, \mathrm{Cu}^{2+}, \mathrm{Zn}^{2+}, \mathrm{Cd}^{2+}$ and $\mathrm{Pb}^{2+}$ exchange for $\mathrm{Na}^{+}$in sedimentary clinoptilolite,North Sardinia, Italy. Micropor. Mesopor.Mater. 37:337-343.

[49] Collela C (1996) Ion Exchange Equilibria in Zeolite Materials. Mineral. Deposita 31:554.

[50] Hafez MB, Nazmy AF, Salem F, Eldesoki M (1978) Fixation mechanism between zeolite and some radioactive elements. J.Radioanal.Chem. 47:115-122.

[51] Al-Anbera M, Al-Anberb ZA (2008) Utilization of natural zeolite as ion-exchange and sorbent material in the removal of iron. Desalination 225:70-81.

[52] Lina J, Zhan Y, Zhu Z, Xing Y (2011) Adsorption of tannic acid from aqueous solution onto surfactant-modified zeolite. J.Hazard.Mater. 193:102-111.

[53] Jiménez-Cedillo MJ, Olguín MT, Fall Ch, Colín A (2011) Adsorption capacity of iron- or iron-manganese-modified zeolite-rich tuffs for $\mathrm{As}(\mathrm{III})$ and $\mathrm{As}(\mathrm{V})$ water pollutants. Appl. Clay Sci. 54:206-216.

[54] Perić J, Trgo M, Vukojević Medvidović N (2004) Removal of zinc, copper and lead bynatural zeolite-a comparison of adsorption isotherms. Water Res. 38:1893-1899. 
[55] Yousefa RI, El-Eswed B, Al-Muhtasebc AH (2011) Adsorption characteristics of natural zeolites as solid adsorbents for phenol removal from aqueous solutions: Kinetics, mechanism, and thermodynamics studies. Chem. Eng.J. 171:1143-1149.

[56] Noroozifar M, Khorasani-Motlagh M, Fard PA (2009) Cyanide uptake from wastewater by modified natrolite zeolite-iron oxyhydroxide system: Application of isotherm and kinetic models. J.Hazard.Mater. 166:1060-1066.

[57] Misaelides P, Zamboulis D, Sarridis Pr, Warchoł J, Godelitsas A (2008) Chromium (VI) uptake bypolyhexamethylene-guanidine-modified natural zeolitic materials. Micropor.Mesopor.Mater. 108:162-167.

[58] Chutia P, Kato Sh, Kojima T, Satokawa S (2009) Adsorption of As(V) on surfactantmodified natural Zeolites. J.Hazard.Mater. 162:204-211.

[59] Widiastuti N, Wu H, Ming Ang H, Zhang D (2011) Removal of ammonium from greywater using natural zeolite. Desalination 277:15-23.

[60] Lina J, Zhan Y, Zhub Z (2011) Adsorption characteristics of copper (II) ions from aqueous solution onto humic acid-immobilized surfactant-modified zeolite. Colloids Surf. A: Physicoch. Eng. Aspect 384:1-3:9-16.

[61] Karatas M (2012) Removal of $\mathrm{Pb}(\mathrm{II})$ from water by natural zeolitic tuff: Kinetics and Thermodynamics. J.Hazard. Mater.199-200:383-389.

[62] Rajić N, Stojakovic Dj, Jevtić S, Zabukovec Logar N, Kovač J, Kaučič V (2009) Removal of aqueous manganese using the natural zeolitic tuff from the Vranjska Banja deposit in Serbia. J.Hazard.Mater. 172:1450-1457.

[63] Baskan MB, Pala A (2011) Removal of arsenic from drinking water using modified natural zeolite. Desalination 281:396-403.

[64] Malekian R, Abedi-Koupai J, Saeid Eslamian S, Farhad Mousavi S, Abbaspour KC, Afyuni M (2011) Ion exchange process for ammonium removal and release using natural Iranian zeolite. Appl. Clay Sci. 51:323-329.

[65] Kurniawan TA, Chan GYS, Lo WH, Babel S (2006) Physico-chemical treatment techniques for wastewater laden with heavy metals. Chem.Engin.J. 118:83-98.

[66] Fu F, Wang Q (2011) Removal of heavy metal ions from wastewaters: A review. J. Environ. Manage. 92:407-418.

[67] Choo KH, Lee H, Choi SJ (2005) Iron and manganese removal and membrane fouling during UF in conjunction with prechlorination for drinking water treatment. J.Memb.Sci. 267:18-26.

[68] Al-Anbera M, Al-Anberb ZA (2008) Utilization of natural zeolite as ion-exchange and sorbent material in the removal of iron. Desalination 225:70-81.

[69] Ćurković L, Cerjan Stefanović Š, Filipan T (1997) Metal ion exchange by natural and modified zeolites. Water Res. 31:6:1379-1382.

[70] Leyva-Ramos R, Jacobo-Azuara A, Diaz-Flores PE, Guerrero-Coronado RM, MendozaBarron J, Berber-Mendoza MS (2008) Adsorption of chromium (VI) from an aqueous solution on a surfactant-modified zeolite. Coll.Surf. A: Physicochem. Eng. Aspects 330:35-41.

[71] Woinarskia AZ, Snapeb I, Stevensa GW, Starkb SC (2003) The effects of cold temperature on copper ion exchange by natural zeolite for use in a permeable reactive barrier in Antarctica. Cold Reg. Sci.Technol. 37:159-168. 
[72] Rajić N, Stojaković Dj, Jovanović M, Zabukovec Logar N, Mazaj M, Kaučič V (2010) Removal of nickel(II) ions from aqueous solutions using the natural clinoptilolite and preparation of nano-NiO on the exhausted clinoptilolite. Appl. Surf. Sci. 257:1524-1532.

[73] Shavandi MA, Haddadian Z, Ismail MHS, Abdullah N, Abidin ZZ (2012) Removal of $\mathrm{Fe}(\mathrm{III}), \mathrm{Mn}(\mathrm{II})$ and $\mathrm{Zn}(\mathrm{II})$ from palm oil mill effluent (POME) by natural zeolite. J. Taiwan Ins.Chem. Engin. (in press).

[74] Dal Bosco SM, Jimenez RS, Carvalho WA (2005) Removal of toxic metals from wastewater by Brazilian natural scolecite. J.Coll.Interf.Sci. 281:424-431.

[75] Sheta AS, Falatah AM, Al-Sewailem MS, Khaled EM, Sallam ASH (2003) Sorption characteristics of zinc and iron by natural zeolite and bentonite. Micropor. Mesopor. Mater. 61:127-136.

[76] Taffarel SR, Rubio J (2009) On the removal of Mn2+ ions by adsorption onto natural and activated Chilean zeolites. Mineral. Engin. 22:336-343.

[77] Katsou E, Malamis S, Tzanoudaki M, Haralambous KJ, Loizidou M (2011) Regeneration of natural zeolite polluted by lead and zinc in wastewater treatment systems. J.Hazard.Mater. 189:773-786.

[78] Farkaš A, Rožić M, Barbarić-Mikočević T (2005) Ammonium exchange in leakage waters dumps using natural zeolite from the Krapina region,Croatia, J.Hazard.Mater. 117:1:2533.

[79] Perego C, Bagatin R, Tagliabue M, Vignola R (2012) Zeolites and Related Mesoporous Materials for Multi-talented Environmental Solutions, Micropor.Mesopor.Mater., doi: http://dx.doi.org/10.1016/j.micromeso.2012.04.048 (Accepted Manuscript).

[80] Vukojević Medvidović N, Perić J, Trgo M (2006) Column performance in lead removal from aqueous solution by fixed bed of natural zeolite-clinoptilolite. Sep. Purif. Tech. 49:3:237-244.

[81] Vukojević Medvidović N, Perić J, Trgo M, Mužek N (2007) Removal of lead ions by fixed bed of clinoptilolite - The effect of flow rate. Micropor.Mesopor.Mater. 105:3:298304.

[82] Mercer BW, Ames LL, Touhill CJ, Van Slyke WJ, Dean RB (1970) Ammonia Removal from Secondary Effluents by Selective Ion Exchange. J.Wat.Pollut.Contr.Fed. 42:20:95107.

[83] Koon JH, Kaufmann WJ (1975) Ammonia Removal from Municipal Wastewaters by Ion Exchange. J.Wat.Pollut.Contr.Fed. 47:3:448-465.

[84] El Akrami HA (1991) Column Studies of Ammonium Ion Exchange on Clinoptilolite, MS. Thesis, METU, Ankara.

[85] Abusafa A (1995) Column Studies of Ammonium and Cesium Exchanges on Bigadic Clinoptilolite, MS. Thesis, METU, Ankara.

[86] Milan Z, Sénchez E, Weiland P, de Las Pozas C, Borja R, Mayari R, Rovirosa N (1997) Ammonia Removal from Anaerobically Treated Piggery Manure by Ion Exchange in Columns Packed With Homoionic Zeolite. Chem.Engin.J. 66:1:65-71.

[87] Nguyen ML, Tanner CC (1998) Ammonium Removal from Wastewaters Using Natural New Zealand Zeolites. New Zealand. J.Agri.Res. 41:3:427-446. 
[88] Roberto J, Hernández S, M. Andrés J, Ruiz C (2009) Ion exchange uptake of ammonium in wastewater from a Sewage Treatment Plant by zeolitic materials from fly ash. J.Hazard.Mater. 161:2-3:781-786.

[89] Lahav O, Green M (1998) Ammonium removal using ionexchange and biological regeneration. Water Res. 32:2019-2028.

[90] Petruzzelli D, Pagano M, Tiravanti G, Passino R (1999) Lead Removal and Recovery from Battery Wastewaters by Natural Zeolite Clinoptilolite. Sol.Extra.Ion Exchan.17:3:677-694.

[91] Abd El-Hady HM, Grünwald A, Vlčková K, Zeithammerová J (2001) Clinoptilolite in Drinking Water Treatment for Ammonia Removal. Acta Polytech. 41;1;41-45.

[92] Demir A, Günay A, Debik E (2002) Ammonium Removal from Aqueous Solution by Using Packed Bed Natural Zeolite. Water SA, 28:3:329-336.

[93] Inglezakis VJ, Loizidou MD, Grigoropoulou HP (2002) Equilibrium and Kinetic Ion Exchange Studies of $\mathrm{Pb} 2+, \mathrm{Cr} 3+, \mathrm{Fe} 3+$ and $\mathrm{Cu} 2+$ on Natural Clinoptilolite. Water Res. 36:11:2784-2792.

[94] Park JB, Lee SH, Lee JW, Lee CY (2002) Lab Scale Experiments for Permeable Reactive Barriers against Contaminated Groundwater with Ammonium and Heavy Metals Using Clinoptilolite (01-29B). J.Hazard.Mater. 95:1-2:65-79.

[95] Bolan NS, Mowatt C, Adriano DC, Blennerhassett JD (2003) Removal of Ammonium Ions from Fellmongery Effluent by Zeolite. Communi. Soil Sci. Plant Analy. 34:1314:1861-1872.

[96] Turan M, Celik MS (2003) Regenerability of Turkish Clinoptilolite for Use in Ammonia Removal from Drinking Water. J.Water Sup. Res.Techn. - AQUA 52:10:59-66.

[97] Rahmani AR, Mahvi AH, Mesdaghinia AR, Nasseri N (2004) Investigation of Ammonia Removal from Polluted Waters by Clinoptilolite Zeolite. J. Environ.Sci.Tech. 1:2:125-133.

[98] Sarioglu M (2005) Removal of Ammonium from Municipal Wastewater Using Natural Turkish (Dogantepe) Zeolite. Sep.Purific.Tech., 41:1-11.

[99] Vukojević Medvidović N, Perić J, Trgo M (2008) Testing of Breakthrough Curves for Removal of Lead Ions from Aqueous Solutions by Natural Zeolite-Clinoptilolite According to the Clark Kinetic Equation. Sep. Sci. Technol. 43:4:944-959.

[100] Perić J, Trgo M, Vukojević Medvidović N, Nuić I (2009) The Effect of Zeolite Fixed Bed Depth on Lead Removal from Aqueous Solutions. Sep. Sci.Technol. 44:13:3113-3127.

[101] Miladinović N, Weatherley LR (2007) Intensification of Ammonia Removal in a Combined Ion-Exchange and Nitrification Column. Chem.Engin.J.135:1-20:15-24.

[102] Šiljeg M, Foglar L, Kukučka M (2010) The Ground Water Ammonium Sorption onto Croatian and Serbian Clinoptilolite. J.Hazard.Mater. 178:1-3:572-577.

[103] Tao YF, Qiu Y, Fang SY, Liu ZY, Wang Y, Zhu JH (2010) Trapping the Lead Ion in Multi-Components Aqueous Solution by Natural Clinoptilolite. J.Hazard.Mater. 180:13:282-288. 